\title{
A Distinct Population of Microglia Supports Adult Neurogenesis in the Subventricular Zone
}

\author{
Anna L. Ribeiro Xavier, ${ }^{1,2}$ Benjamin T. Kress, ${ }^{2}$ Steven A. Goldman, ${ }^{2,3}$ João R. Lacerda de Menezes, ${ }^{1}$ \\ and $\odot$ Maiken Nedergaard ${ }^{2,3}$ \\ ${ }^{1}$ Laboratório de Neuroanatomia Celular, Instituto de Ciências Biomédicas, Centro de Ciências da Saúde, Universidade Federal do Rio de Janeiro, Rio de \\ Janeiro, RJ 21941-902 Brazil, ${ }^{2}$ Center for Translational Neuromedicine, University of Rochester Medical School, Rochester, New York 14642 , and ${ }^{3}$ Center for \\ Basic and Translational Neuroscience, University of Copenhagen, 2200N Copenhagen, Denmark
}

Microglia are involved in synaptic pruning both in development and in the mature CNS. In this study, we investigated whether microglia might further contribute to circuit plasticity by modulating neuronal recruitment from the neurogenic subventricular zone (SVZ) of the adult mouse striatum. We found that microglia residing in the SVZ and adjacent rostral migratory stream (RMS) comprise a morphologically and antigenically distinct phenotype of immune effectors. Whereas exhibiting characteristics of alternatively activated microglia, the SVZ/RMS microglia were clearly distinguished by their low expression of purinoceptors and lack of ATP-elicitable chemotaxis. Furthermore, the in vivo depletion of these microglia hampered the survival and migration of newly generated neuroblasts through the RMS to the olfactory bulb. SVZ and RMS microglia thus appear to comprise a functionally distinct class that is selectively adapted to the support and direction of neuronal integration into the olfactory circuitry. Therefore, this unique microglial subpopulation may serve as a novel target with which to modulate cellular addition from endogenous neural stem and progenitor cells of the adult brain.

Key words: microglia; neuroblasts; neurogenesis; purinergic signaling; subventricular zone

\section{Significance Statement}

Microglial cells are a specialized population of macrophages in the CNS, playing key roles as immune mediators. As integral components in the CNS, the microglia stand out for using the same mechanisms, phagocytosis and cytochemokine release, to promote homeostasis, synaptic pruning, and neural circuitry sculpture. Here, we addressed microglial functions in the subventricular zone (SVZ), the major postnatal neurogenic niche. Our results depict microglia as a conspicuous component of SVZ and its anterior extension, the rostral migratory stream, a pathway used by neuroblasts during their transit toward olfactory bulb layers. In addition to other unique populations residing in the SVZ niche, microglia display distinct morphofunctional properties that boost neuronal progenitor survival and migration in the mammalian brain.

\section{Introduction}

Microglia comprise a distinct phenotype of glia that arise from yolk-sac-derived myeloid progenitors, which invade the CNS at

Received March 29, 2015; revised June 2, 2015; accepted July 1, 2015.

Author contributions: A.L.R.X., B.T.K., S.A.G., J.R.L.d.M., and M.N. designed research; A.L.R.X. performed research; A.L.R.X. and B.T.K. analyzed data; A.L.R.X., B.T.K., S.A.G., and M.N. wrote the paper.

This work was supported by the National Institutes of Health (M.N.) and the Harold and Leila Y. Mathers Charitable Foundation (M.N.). A.L.R.X. was the recipient of graduate fellowships from the Conselho Nacional de Desenvolvimento Científico e Tecnológico and from Coordenação de Aperfeiçoamento de Pessoal de Nível Superior. We thank David Julius (University of California-San Francisco) for kindly providing P2RY12 antibody and Takahiro Takano, Carla M. Furtado, and Celina García for expert technical support.

The authors declare no competing financial interests.

Correspondence should be addressed to Dr Maiken Nedergaard, Center for Translational Neuromedicine, University of Rochester Medical School, Rochester, NY 14642. E-mail: nedergaard@urmc.rochester.edu.

A. Ribeiro Xavier's present address: Neurosciences Paris-Saclay Institute, UMR 9197, CNRS- Université Paris-Sud, Gif-sur-Yvette, 91190 France.

DOI:10.1523/JNEUROSCI.1217-15.2015

Copyright $\odot 2015$ the authors $\quad 0270-6474 / 15 / 3511848-14 \$ 15.00 / 0$ early stages of development (Alliot et al., 1999; Ginhoux et al., 2010; Ginhoux et al., 2013). Traditional roles for microglia include mounting acute responses to injuries, phagocytosis of pathogens and cellular debris, and the release of inflammatory modulators and cytokines (e.g., TNF, IFN, and IL-1; Liu et al., 1998; Gregersen et al., 2000; Nadeau and Rivest, 2000).

Recent studies have expanded our conception of the developmental and functional roles of microglia. At both the neonatal and juvenile stages, microglia engulf developmentally apoptotic immature neurons and prune excess synaptic densities (MarínTeva et al., 2004; Tremblay et al., 2010; Paolicelli et al., 2011; Schafer et al., 2012; Schafer et al., 2013). They concurrently release both cytokines and trophic factors critical for the differentiation of neural progenitor cells (Ueno et al., 2013) and may regulate neuronal survival.

In view of the cytokine responsiveness and production of microglia and their modulation of developmental neuronal and oli- 
godendrocyte production (Butovsky et al., 2006), we investigated whether microglia might play a role in adult neurogenesis. In particular, we postulated that microglia might participate in the regulation of neuronal production in, and recruitment from, the subventricular zone (SVZ), a region that exhibits persistent neurogenesis throughout adulthood. Microglia have been shown previously to influence adult hippocampal circuitry either by cytokine release upon their activation (Battista et al., 2006) or by active phagocytosis in the neurogenic adult dentate gyrus (Sierra et al., 2010). However, in contrast to the local neuronal addition of the dentate granular layer, neuroblasts originating in the SVZ migrate long distances via the rostral migratory stream (RMS), in organized chains, before differentiating into the granular and periglomerular cells of the olfactory bulb (OB) (Lois and AlvarezBuylla, 1994; Lois et al., 1996; Zhao et al., 2008). On that basis, we postulated that microglia residing in the SVZ/RMS might interact in a fundamentally different manner with neuroblasts than do microglia residing in the hippocampus. We posited that microglia might direct the migration of neuroblasts in the RMS in the adult CNS, as suggested by the observation that microglia may direct the migration and differentiation of neural precursors in vitro (Aarum et al., 2003). Earlier analysis of the developing brain also support this concept, because microglia at early postnatal stages display little sign of phagocytosis in the SVZ/RMS niche despite their proximity to neuroblasts (Xavier et al., 2015).

Using a knock-in transgenic mouse strain that has a locus of the fractalkine receptor $C X 3 C R 1$ replaced by the gene encoding GFP (Jung et al., 2000), we identified a distinct population of microglia in the adult forebrain subependyma and olfactory stream. Our observations indicate that this subset of microglial cells is crucial for the migration and survival of neuroblasts during their transit through the RMS to the OB.

\section{Materials and Methods}

Experiments. CX3CR1-EGFP mice on the C57BL/6J background were purchased from Jackson Laboratories (http://jaxmice.jax.org/strain/ 013636.html, strain name B6.129P-CX3CR1tm1Litt/J, stock number 005582). All experiments were performed in accordance with protocols approved by Animal Use Committees at the University of Rochester.

Histology and immunohistochemistry. Animals of either sex were deeply anesthetized by intraperitoneal (i.p.) injections of a mixture of ketamine and xylazine $(\mathrm{K} / \mathrm{X}, 130 / 10 \mathrm{mg} / \mathrm{kg})$ and transcardially perfused with PBS (0.1 м pH 7.4; Sigma-Aldrich) followed by paraformaldehyde 4\% (PFA; Sigma-Aldrich, in PBS 0.1 M, pH 7.4). Brains were dissected and postfixed in PFA $4 \%$ for $3-6 \mathrm{~h}$ at room temperature (RT) for vibratome sectioning (50-100 $\mu \mathrm{m}$; Vibratome Series 3000; Vibratome).

Histological sections were blocked for $1 \mathrm{~h}$ at RT in a PBS containing $0.1 \%$ Triton X-100 (Sigma-Aldrich) solution added with 7\% normal donkey serum (Vector Laboratories) and incubation with antibodies against P2RY12 (1:2000, kindly provided by Dr. David Julius, University of California-San Francisco), P2RY1 and P2RY6 (1:100; Alomone Laboratories), Iba1 (1:500; Wako), CD68 (1:100, AbD Serotec), CD11c (1: 100, AbD Serotec), TREM2 (1:100; Abcam), DCX (1:1000; Millipore), NeuN (1:100; Millipore), GFAP (1:250; Sigma-Aldrich), BLBP (1:100; Millipore), NG2 (1:100; Abcam), Ki67 (1:250; Thermo Scientific), pSTAT6 and STAT6 (1:100; Abcam) was performed overnight at $4^{\circ} \mathrm{C}$. Labeling with isolectin B4 (GS-IB4, Griffonia simplicifolia) was also applied accordingly to manufacturer specifications. Staining was revealed by a $2 \mathrm{~h}$ incubation period at RT with appropriated secondary antibodies conjugated to Cy3 or Cy5 fluorophores (1:250; Jackson ImmunoResearch) and with $\mathrm{Cy} 3$ or Cy5 conjugated to streptavidin (1: 250; Jackson ImmunoResearch). DAPI (4',6-diamidino-2-phenylindole, 1:1000; Sigma-Aldrich) was used for nuclear counterstaining and slides were mounted with ProLong Antifade (Life Technologies). Immunolabeled brain sections were imaged using a confocal microscope (Olympus
FluoView 500) with $40 \times$ [numerical aperture (NA) 1.30] and $60 \times$ oilimmersion (NA 1.25) objective lens (Olympus). Acquired images were adjusted for brightness and contrast using FIJI/ImageJ software.

The coordinates of sections analyzed in this study were accessed by comparing the cytoarchitecture revealed by DAPI counterstaining to the adult mouse brain atlas (Paxinos and Franklin, 2004). In the parasagittal plane, sections $0-0.2 \mathrm{~mm}$ from bregma (left and right) were analyzed. For coronal sections, the following coordinates were used: (1) SVZ: sections ranging from 0.50 to $0.14 \mathrm{~mm}$ anterior to bregma, (2) RMS: sections ranging from 1.42 to $3.00 \mathrm{~mm}$ anterior to bregma, and (3) OB: sections ranging from 4.00 to $5.00 \mathrm{~mm}$ anterior to bregma.

For quantification, 2 sections $(50 \mu \mathrm{m})$ per animal $(n=6)$ (total of 12 sections) were analyzed. In the analysis of CX3CR1-EGFP ${ }^{+}$cell density, the area of micrographs was measured using DAPI staining as a reference and the number of $z$-stacks and step size were used to calculate the analyzed tissue volume. For SVZ, the analyzed volume was $0.75 \pm 0.13$; for RMS, it was $1.32 \pm 0.16$; and for $\mathrm{OB}$, it was $2.94 \pm 0.5 \mathrm{~mm}^{3}$. For analysis of macrophagic markers, the absolute number of Iba1, IB4, CD68, and CD11c cells observed within the SVZ, RMS, and OB (granule cell layer, mitral, external plexiform and glomerular layers) delimited by DAPI counterstaining was used to compare with the population of CX3CR1-EGPF-expressing cells in the same areas. For analysis of the number of BrdU cells, only cells distributed along the SVZ, RMS, and within the distinct OB layers were counted, using DAPI counterstaining as reference to delimit the analyzed areas.

ELISArray assays. SVZ and CTX cells were isolated based in a modified version of the protocol established by Wang and collaborators (Wang et al., 2010; Wang et al., 2013). Mice were deeply anesthetized and transcardially perfused with $\mathrm{HBSS}^{-}$(Life Technologies). Brains were rapidly removed from the skull and kept on ice-cold $\mathrm{HBSS}^{+}$(HBSS containing $1 \%$ horse serum; Life Technologies; $\mathrm{MgCl}_{2} 400 \mathrm{~mm}$; HEPES $1 \mathrm{~mm}$, and DNaseI $2.000 \mathrm{U} / \mathrm{ml}$; Sigma-Aldrich). Regions of interest were dissected out, washed in $\mathrm{HBSS}^{-}$, and tissue was incubated with activated papain (50 U, PAPL Worthington in Pipes working solution added with EDTA $11 \mathrm{~mm}$ and L-cysteine-HCl $55 \mathrm{~mm}$; Sigma-Aldrich) for $50 \mathrm{~min}$ at $37^{\circ} \mathrm{C}$. Cells were mechanically dissociated in the presence of MEM containing 7.5\% BSA (both from Life Technologies), DNaseI, and 5\% FBS (Life Technologies). Cells were filtered in prewet cell strainers (100 $\mu \mathrm{m}$ mesh; BD Biosciences), centrifuged for $8 \mathrm{~min}$ at $1500 \mathrm{rpm}$, ressuspended, and applied into cold Percoll gradient (90\% Percoll; Sigma-Aldrich, in PBS $\mathrm{pH} 7.4 ; \mathrm{HCl} 2 \mathrm{M}$ ). Cellular suspension was centrifuged for $15 \mathrm{~min}$ at 1500 rpm, resuspended, and submitted to a final spin for $10 \mathrm{~min}$ at $1500 \mathrm{rpm}$. Cells were plated $\left(1-3 \times 10^{5} \mathrm{cells} / \mathrm{ml}\right)$ in DMEM GlutaMAX supplemented with B-27 added to the antimycotic $1 \%$ and antibiotic mixture 10 $\mathrm{mg} / \mathrm{ml}$ (Life Technologies) and plated in culture dishes overnight in an incubator at $37^{\circ} \mathrm{C} ; 5 \% \mathrm{CO}_{2} / 95 \% \mathrm{O}_{2}$. Media collected from dissociated cells were analyzed by ELISA using the Common Cytokines MultiAnalyte ELISArray Kit (QIAGEN), which analyzes a panel of 12 mouse cytokines (IL- $\alpha$, IL-1 $\beta$, IL-2, IL-4, IL-5, IL-6, IL-10, IL-12, IL-13, IL$17 \mathrm{~A}, \mathrm{G}-\mathrm{CSF}$, and GM-CSF), according to the manufacturer's instructions all at once and under uniform conditions.

ATP assays. CX3CR1-EGFP ${ }^{+}$cells responsiveness to ATP was analyzed by multiphoton imaging. CX3CR1-EGFP mice were euthanized and their brains quickly removed from the skull. To maintain cell viability, tissue was kept in ice-cold artificial CSF (ACSF, NaCl 119 mм; $\mathrm{NaHCO}_{3} 26.2 \mathrm{~mm}$; KCl $2.5 \mathrm{~mm} ; \mathrm{NaH}_{2} \mathrm{PO}_{4} 1 \mathrm{~mm} ; \mathrm{MgCl}_{2} 1.3 \mathrm{~mm}$, and glucose $10 \mathrm{~mm}$; Sigma-Aldrich) continuously perfused with $5 \% \mathrm{CO}_{2} /$ $95 \% \mathrm{O}_{2}$. Parasagittal slices $(300 \mu \mathrm{m})$ were obtained by vibratome sectioning (Vibratome Series 3000; Vibratome) and placed into ice-cold ACSF containing borosilicate chambers (EMS; Lab-Tek) for imaging. Glass pipettes (10-20 $\mu \mathrm{m}$ diameter; World Precision Instruments) filled with ATP (1 mM; Sigma-Aldrich) were positioned directly to cortical parenchyma or into the RMS and exogenous ATP was allowed to diffuse or applied with a 10 psi pressure force for $0.1 \mathrm{~s}$ (Picospritzer III; Parker). Imaging scanning was performed in a custom-built microscope combining Mai Tai laser (Spectra Physics), FV300 scan box (Olympus), and BX-50WI upright microscope (Olympus), equipped with a $40 \times$ waterimmersion lens (NA 0.80, LUMPlanFI/IR; Olympus). EGFP was excited at $900 \mathrm{~nm}$ and detected with 515/50 band filter and XYZT stack se- 

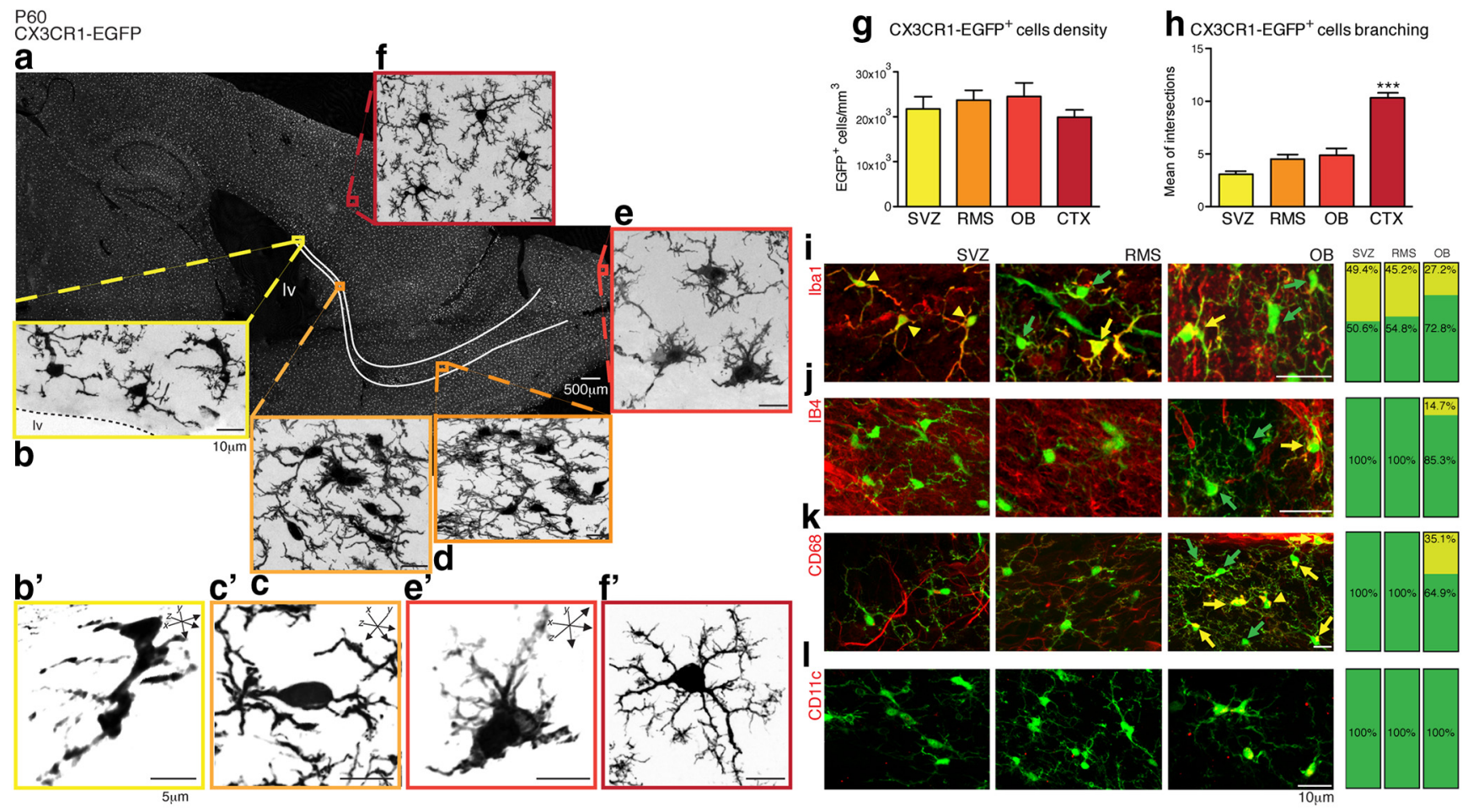

Figure 1. CX3CR1-EGFP ${ }^{+}$cells displaying a distinct morphology comprise a component of the adult SVZ/RMS/OB. Confocal microscopy analysis of brain parasagittal section obtained from adult CX3CR1-EGFP mice (P60) reveals that microglia (EGFP, gray) are distributed throughout the brain $(\boldsymbol{a})$ and also in the SVZ $(\boldsymbol{b})$, along the RMS (c, $\boldsymbol{d})$ and OB (e). Microglia within the SVZ niche have enlarged cell bodies and display an immature morphology $\left(\boldsymbol{b}^{\prime}, \boldsymbol{c}^{\prime}, \boldsymbol{e}^{\prime}\right)$. Despite their distinct morphology compared with their counterparts in the cortex (CTX), in which typical ramified microglia are observed $\left(\boldsymbol{f}, \boldsymbol{f}^{\prime}\right)$, the cell density is similar in all analyzed regions (SVZ: $22 \times 10^{3} \pm 2.8 \times 10^{3} ; \mathrm{RMS}: 24 \times 10^{3} \pm 2.2 \times 10^{3} ; 0 \mathrm{~B}: 24.5 \times 10^{3} \pm 3 \times 10^{3} ;$ (TX:20 $2010^{3} \pm 1.7 \times 10^{3} ;$ mean \pm SEM; $p>0.05$, Tukey's multiple-comparisons test; $\boldsymbol{g}$ ). Along the SVZ niche, Scholl analysis of cell branching shows that microglia are markedly less ramified than their counterparts distributed in the cortical parenchyma (SVZ: $3.01 \pm 0.3 ; \mathrm{RMS}: 4.5 \pm 0.4 ; 0 \mathrm{~B}: 4.9 \pm 0.6 ;$ (TX: $10.3 \pm 0.5 ;$ mean \pm SEM of intersections to concentric circles; $p=0.0001$, Kruskal-Wallis test; $\boldsymbol{h}$ ). Analysis of brain sections obtained from CX3CR1-EGFP transgenic mice (P60) and stained for Iba1 (i, red), Isolectin B4 (j, red), and CD68 (k, red) show that the majority of CX3CR1-EGFP ${ }^{+}$cells (green, indicated by green arrows) are not colabeled in the SVZ, RMS, or OB (few double-labeled cells are indicated by yellow arrows). Despite the lack of immunoreactivity to these markers, $\mathrm{CX3CR}^{+}$-EGFP ${ }^{+}$cells present in the SVZ/RMS/OB do not appear to be dendritic cells, as they do not express CD11C (I). Scale bars: $\boldsymbol{a}-\boldsymbol{f}, \boldsymbol{i}-\boldsymbol{I}, 10 \mu \mathrm{m} ; \boldsymbol{b}^{\prime}, \boldsymbol{c}^{\prime}, \boldsymbol{e}^{\prime}, \boldsymbol{f}^{\prime}, 5 \mu \mathrm{m}$.

quences were captured every $15 \mathrm{~s}$, for a total interval of $15 \mathrm{~min}$. The setup is controlled by FluoView software (Olympus).

BrdU analysis. We applied the brominated analog of thymidine, BrdU (Sigma-Aldrich, $10 \mathrm{mg} / \mathrm{ml}$ in $\mathrm{NaOH} 0.007 \mathrm{~N}$ ) to track proliferative cells in CX3CR1-EGFP mice, which received a single pulse of BrdU into the intraperitoneal cavity $(150 \mathrm{mg} / \mathrm{kg}$. i.p.). Proliferative cells were revealed by immunohistochemistry using a specific primary antibody (1:100; $\mathrm{AbD}$ Serotec), as described in the previous section, but before blocking, sections were treated for $1 \mathrm{~h}$ with $\mathrm{HCl} 1 \mathrm{M}$ at RT under agitation to allow labeling of nuclear DNA (Tang et al., 2007).

Mac1-SAP-mediated microglia depletion. To specifically and locally deplete microglial cells in the SVZ region, we used saporin (SAP) toxin conjugated to a monoclonal antibody CD11b (or Mac-1, macrophage-1 antigen) for selective incorporation by macrophages. Animals were anesthetized (K/X, 130/10 mg/kg, i.p.) and, once reflexes were terminated, animals were placed in a stereotaxic frame (Stoelting). Additional anesthetic injections corresponding to $1 / 2$ of the initial $\mathrm{K} / \mathrm{X}$ dose were given as necessary. Cranial windows were opened in mice skull and a microsyringe (10 $\mu$ l, Model 1701 RN SYR 1700 Series Gastight; Hamilton) was positioned at the following coordinates: anterior $0.5 \mathrm{~mm}$, lateral $0.48 \mathrm{~mm}$ in relation to bregma and $2.5 \mathrm{~mm}$ depth from the pial surface. Using a microsyringe pump controller (Micro 4; World Precision Instruments), 1-1.5 $\mu \mathrm{l}$ of Mac1-SAP $(150 \mu \mathrm{g} / \mathrm{ml})$, rat IgG-SAP $(200 \mu \mathrm{g} / \mathrm{ml})$, or unconjugated SAP $(50 \mu \mathrm{g} / \mathrm{ml}$; Advanced Target Systems) were applied at a $100 \mathrm{nl} / \mathrm{min}$ rate. Soon after surgery, a group of animals received a dose of BrdU (150 mg/kg, i.p.) to access SVZ microglia depletion effects on neuroblasts migration 4-7 d later. Proliferative rates in injected animals were analyzed in mice that received a single pulse of $\mathrm{BrdU}(150 \mathrm{mg} / \mathrm{kg}$, i.p.) $1 \mathrm{~h}$ before euthanasia and $24 \mathrm{~h}$ after microglia depletion.
Statistical analysis. All histograms are expressed as mean \pm SEM. Raw data, obtained in distinct experimental approaches used in the present work, were analyzed statistically using Prism (GraphPad Software) and the normality of the data was examined with Shapiro-Wilk test. Tukey's multiple-comparisons test, $t$ tests, and unpaired $t$ tests were used where appropriate.

\section{Results}

Adult SVZ harbors a distinct microglial phenotype

Laser-scanning micrographs revealed that CX3CR1-EGFPexpressing microglial cells distributed throughout the mouse brain at postnatal day 60 (P60) (Fig. 1a) are also present in the SVZ (Fig. 1b) and its anterior extension, the RMS (Fig. 1c,d). Within the OB, where interneurons are continuously replaced by SVZ-generated precursors, we observed amoeboid CX3CR1$\mathrm{EGFP}^{+}$microglia in the glomerular layer (Fig. 1e, gl). In contrast, typical ramified microglia are observed in the cerebral cortex (CTX) parenchyma of adult mice (Fig. $1 f$ ). Our results reveal that microglia are a cellular component of the SVZ neurogenic niche in its entire extension, whose density is comparable to the cortical parenchyma (SVZ: $22 \times 10^{3} \pm 2.8 \times 10^{3}$; RMS: $24 \times 10^{3} \pm$ $2.2 \times 10^{3}$; OB: $24.5 \times 10^{3} \pm 3 \times 10^{3}$; CTX: $20 \times 10^{3} \pm 1.7 \times 10^{3}$ cells $/ \mathrm{mm}^{3}$, mean \pm SEM; $n=6$ animals, $p>0.05$, Tukey's multiple-comparisons test; Fig. $1 g$ ). Remarkably, microglia along the SVZ, RMS, and OB regions display a distinct morphology, with enlarged cell somata and relatively few, and notably thick, processes (Fig. $1 b^{\prime}, c^{\prime}, e^{\prime}$ ), differing from the ramified microglia present in the CTX (Fig. $1 f^{\prime}$ ). Indeed, microglial cells branching 
along the SVZ/RMS/OB niche is significantly less exuberant than observed in the CTX, as depicted by Scholl analysis (SVZ: $3.0 \pm$ 0.3; RMS: $4.5 \pm 0.4$; OB: $4.9 \pm 0.6$; CTX: $10.3 \pm 0.5$ intersections with concentric arbitrary rays; $n=8$ cells per region, $p=0.0001$, 1-way ANOVA, Kruskal-Wallis test; Fig. 1h).

Notably, the commonly used microglia/macrophage markers Iba1, isolectin $\mathrm{B}_{4}$, and $\mathrm{CD} 68$ (Fig. $1 i-k$, respectively), failed to label most CX3CR1-EGFP ${ }^{+}$cells in the SVZ, RMS, and OB. Indeed, of all CX3CR1-EGFP ${ }^{+}$cells in the SVZ, RMS, and OB, less than half express Iba1. Similarly, isolectin $\mathrm{B}_{4}{ }^{+}$and $\mathrm{CD}_{6}{ }^{+}$cells are observed only within the $\mathrm{OB}$, in which they respectively comprise only $14.7 \%$ and $35.1 \%$ of all CX3CR1-EGFP ${ }^{+}$cells. Notwithstanding the lack of common microglial markers, CX3CR1$\mathrm{EGFP}^{+}$cells present in the SVZ and RMS also lack a dendritic cell phenotype and do not express CD11c (Fig. 1l).

CX3CR1-EGFP ${ }^{+}$cells appear to comprise a pool of regionally distinct microglia that pervade the entire rostral neurogenic pathway, from the anterior SVZ to the OB, which may be readily distinguished both antigenically and morphologically from microglia of the surrounding anteroventral forebrain.

\section{SVZ microglia express phosphorylated STAT6 and release a distinct set of cytokines}

Microglial cytokines may act as trophic agents in addition to serving as immune modulators. For example, IL-4 and IL-6 typically act as anti-inflammatory and pro-inflammatory mediators, respectively (Scheller et al., 2011). However, these agents also promote neurodendrogenesis and oligodendrogenesis from adult stem cells (Butovsky et al., 2006) and can modulate the self-renewal of neural progenitor cells in vitro (Covey et al., 2011). An ELISA assay was used to profile those cytokines released in the SVZ. Briefly, SVZ tissue was dissected from CX3CR1-EGFP mice (P30; $n=16$ mice equally distributed in two independent experiments) and dissociated with papain as described previously (Wang et al., 2010; Wang et al., 2013). The identity of isolated cells was evaluated by immunocytochemistry and multiple $\mathrm{EGFP}^{+}$microglial cells, as well as a few $\mathrm{GFAP}^{+}, \mathrm{NG}^{+}$, and $\mathrm{DCX}^{+}$cells corresponding to astroglia, oligodendroglia, and neuroblasts, respectively, were found. BLBP and NeuN cells were absent (Fig. 2a), indicating that neither immature radial glia nor neurons were present in the SVZ cell dissociates. Culture media were collected $24 \mathrm{~h}$ after plating and, consistent with the cytokine expression profile detected in dissociated neonatal SVZ cells (Shigemoto-Mogami et al., 2014), we found that IL-1 $\beta$ (5.7 \pm 0.5 $\mathrm{ng} / \mathrm{ml}), \mathrm{IL}-4(1.6 \pm 0.2 \mathrm{ng} / \mathrm{ml})$, IL-6 $(5.3 \pm 0.4 \mathrm{ng} / \mathrm{ml}), \mathrm{IL}-10$ $(1.2 \pm 0.2 \mathrm{ng} / \mathrm{ml})$, and GM-CSF $(6.3 \pm 0.5 \mathrm{ng} / \mathrm{ml})$ are all released by mature SVZ cells (Fig. $2 b)$. In contrast, only IL- $1 \beta(2.9 \pm 0.3$ $\mathrm{ng} / \mathrm{ml})$ and GM-CSF $(6.2 \pm 0.6 \mathrm{ng} / \mathrm{ml})$ are released by cortical cells (Fig. 1f). IL-1 $\alpha$, IL-2, IL-5, IL-12a, IL-13, IL-17a, and G-CSF are either not released or are released at undetectable levels. These data suggested that IL-4, IL-6, and IL-10 are expressed differentially in the SVZ.

IL-4 exhibits a neuroprotective role upon microglial activation (Chao et al., 1993; Zhao et al., 2006). Together with the anti-inflammatory cytokine IL-10, the two are capable of triggering the alternatively activated macrophage phenotype through the phosphorylation-dependent activation of STAT6 (Biswas and Mantovani, 2010). Given the expression of IL-4 and IL-10 in the SVZ, we used immunohistochemistry to evaluate the expression of STAT6 in its active, phosphorylated (pSTAT6) state. CX3CR1EGFP $^{+}$cells in the SVZ exhibit a nuclear distribution of pSTAT6 (Fig. $2 c-e$ ), in contrast to the lack of pSTAT6 immunolabeling of cortical microglia (Fig. $2 g-i$ ), suggesting that the SVZ/RMS neu- rogenic niche includes a cohort of alternatively activated microglial cells.

\section{SVZ/RMS microglia express low levels of purine receptors and are functionally unresponsive to ATP}

The distinct morphology of microglial cells in SVZ/RMS/OB led us to investigate whether they express the purine receptor P2RY12, which has been linked previously to direct process extension and phagocytosis by microglia in other brain regions (Haynes et al., 2006). We found that P2RY12 immunoreactivity was markedly suppressed in the SVZ/RMS compared with surrounding structures (Fig. 3a). Remarkably, the region of low P2RY12 expression precisely coincides with the borders of the SVZ/RMS, a cell dense region readily visualized by DAPI counterstaining (Fig. $3 b$ ). Furthermore, within the SVZ/RMS pathway, where morphologically distinct CX3CR1-EGFP ${ }^{+}$cells are observed (Fig. 3c), P2RY12 accumulates intracellularly in CX3CR1-EGFP ${ }^{+}$microglia (Fig. $3 d-f$ ) rather than along cell processes. In contrast, CX3CR1-EGFP ${ }^{+}$cortical microglia expressed $\mathrm{P} 2 \mathrm{RY} 12^{+}$plaques (Fig. $3 g$ ) that were primarily localized in processes, as described previously (Haynes et al., 2006), as well as intracellularly (Fig. 3h,i).

We have also analyzed the distribution of the UTP receptor P2RY6, a microglial receptor that plays a key role for phagocytosis (Koizumi et al., 2007). Along the SVZ/RMS extension, low levels of P2RY6 are detected in adult mice and only small numbers of CX3CR1-EGFP ${ }^{+}$cells exhibit a low level of expression of this receptor compared with regions outside of the SVZ/RMS (Fig. 3j).

Notably, P2RY1 is expressed throughout the SVZ/RMS migratory pathway (Fig. $3 k, l$ ). In fact, the high P2RY1 immunoreactivity within the SVZ/RMS reflects the expression of this receptor by $\mathrm{DCX}^{+}$neuroblasts (Fig. $3 \mathrm{~m}$ ), consistent with a previous report demonstrating the importance of $\mathrm{P} 2 \mathrm{RY} 1$ for guiding neuroblast migration (Cao et al., 2013).

We reasoned that the low expression of purine receptors (P2RY1, P2RY6, and P2RY12) by SVZ/RMS microglia predicted that their responsiveness to ATP would be relatively attenuated. To address this possibility, we next assessed microglial process motility in response to local ATP administration (Haynes et al., 2006). ATP (1 mM) was injected using glass pipettes for $0.1 \mathrm{~s}$ with at 10 psi or by simple diffusion in either the CTX or RMS of acute slices obtained from CX3CR1-EGFP mice (P60, $n=6)$. The distance from ATP-filled glass pipettes to analyzed microglia cells in the CTX were $72.0 \pm 12.3 \mu \mathrm{m}(n=3$ animals; 9 slices analyzed in total) and in the RMS were $80.3 \pm 13.3 \mu \mathrm{m}$ ( $n=3$ animals; 11 slices analyzed in total; mean $\pm \mathrm{SEM} ; p=0.66$; $t$ test). Twophoton imaging analysis showed that cortical microglial processes avidly extend toward the site of ATP injection (Fig. 4a, $a^{\prime}$ ), whereas ATP-stimulated process movement by RMS microglia is barely appreciable (Fig. $4 b, b^{\prime}$; baseline CTX: $1.23 \pm 0.15$; ATP CTX: $2.83 \pm 0.33 \mu \mathrm{m}$; baseline RMS: $1.05 \pm 0.13$; ATP RMS: $1.13 \pm 0.14 ;$ mean \pm SEM; $p<0.0005$; Mann-Whitney test). We also compared the velocity of single processes in response to ATP in the CTX and RMS and found a significant increase in the velocity of cortical microglial process movement relative to CX3CR1-EGFP ${ }^{+}$processes of RMS microglia, which are essentially unresponsive to ATP (baseline CTX: $0.08 \pm 0.01$; ATP CTX: $0.19 \pm 0.02 \mu \mathrm{m} / \mathrm{min}$; baseline RMS: $0.07 \pm 0.01$; ATP RMS: $0.08 \pm 0.01 ;$ mean \pm SEM; $p<0.0005$; Mann-Whitney test). 

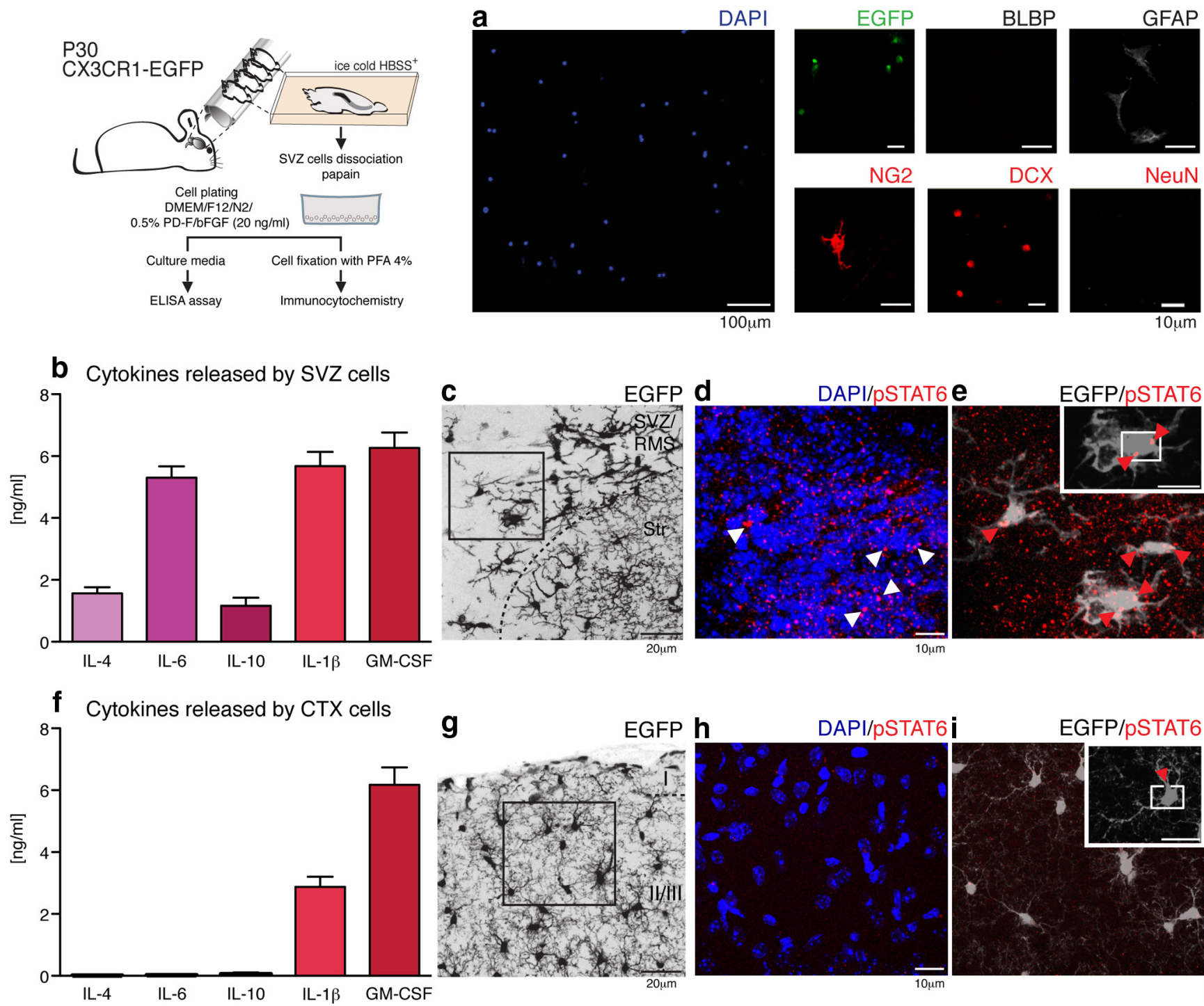

g

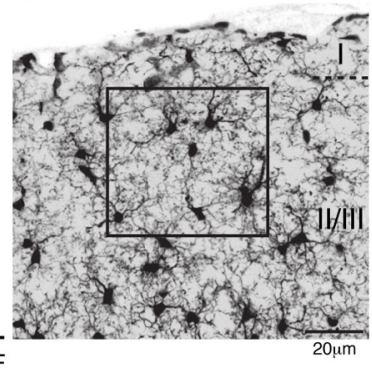

EGFP $\mathbf{h}$

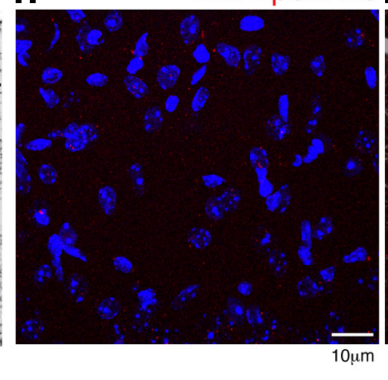

DAPI/pSTAT6 i

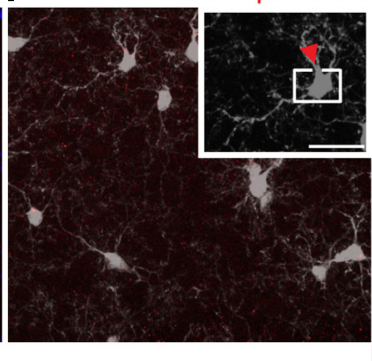

Figure 2. The adult SVZ is enriched in cytokines that promote neurogenesis. The schematic depicts the culture of SVZ cells. These were plated at density of $1-3 \times 10^{5}$ cells/ml and their phenotype was assessed by immunocytochemistry. Dissociated cells correspond to microglia (EGFP, green), astrocyte/astrocyte-like stem cells (GFAP, gray), cells of the oligondendroglial lineage (NG2, red), and neuroblasts ( $D C X$, red). BLBP ${ }^{+}$astroglia and mature neurons $\left(\mathrm{NeuN}^{+}\right)$were not observed $(\boldsymbol{a})$. Shortly before fixation, culture media were collected and the cytokine-release profiles of SVZ cells were assessed by ELISArray assay. IL-1 $\beta(5.7 \pm 0.5 \mathrm{ng} / \mathrm{ml})$, IL-4 $(1.6 \pm 0.2 \mathrm{ng} / \mathrm{ml})$, IL-6 $(5.3 \pm 0.4 \mathrm{ng} / \mathrm{ml}), \mathrm{LL}-10(1.2 \pm 0.2 \mathrm{ng} / \mathrm{ml})$, and GM-CSF $(6.3 \pm 0.5 \mathrm{ng} / \mathrm{ml})$ were released by mature SVZ cells (b). In contrast, only IL-1 $\beta(2.9 \pm 0.3 \mathrm{ng} / \mathrm{ml})$ and GM-CSF $(6.2 \pm 0.6 \mathrm{ng} / \mathrm{ml})$ were released at detectable levels by cortical celll $(\boldsymbol{f})$. IL- $1 \alpha$, IL-2, IL-5, IL-12a, IL- 13 , IL- $17 \mathrm{a}$, and G-CSF were either not released or released at undetectable levels. The presence of IL-4 and IL-10 led us to investigate whether SVZ/RMS CX3CR1-EGFP ${ }^{+}$cells corresponded to alternatively activated-microglia, by immunostaining for PSTAT6, the active form of STAT6 implicated in the determination of this phenotype. c, CX3CR1-EGFP ${ }^{+}$cells surrounding the lateral ventricles (EGFP, gray) exhibit a nuclear distribution (counterstaining by DAPI, blue) of pSTAT6 (red) (d,e, arrowheads). In contrast, cortical (CTX), ramified microglia $(\boldsymbol{g})$ show only rare staining ( $\boldsymbol{h}, \boldsymbol{i}$, red arrowhead). Scale bars: $\boldsymbol{a}, 100$ and $10 \mu \mathrm{m} ; \boldsymbol{c}, \boldsymbol{g}, 20 \mu \mathrm{m} ; \boldsymbol{d}, \boldsymbol{e}, \boldsymbol{h}, \boldsymbol{i}, 5 \mu \mathrm{m}$.

\section{Microglia-mediated phagocytosis in the SVZ, RMS, and OB regions}

Another important functional role of microglial cells is phagocytosis of apoptotic neurons. Purinergic "find me, eat me" signals, transduced through microglial P2Y-family receptors, have been shown to play an important role in this process (Koizumi et al., 2007). Because P2RY6 is an especially prominent ATP-sensing phagocytic receptor and CX3CR1-EGFP ${ }^{+}$cells in the SVZ/RMS expressed low levels of P2RY6 (Fig. 3j), we investigated whether microglial phagocytosis is suppressed within the RMS. Confocal optical sections failed to reveal evidence of any $\mathrm{DCX}^{+}$fragments internalized by CX3CR1-EGFP ${ }^{+}$bulges, suggesting a lack of neuroblast phagocytosis (Fig. 5a,b). To further assess the phagocytic activity of SVZ/RMS CX3CR1-EGFP ${ }^{+}$microglia, we then attempted to track the remnants of newborn cells by administering a single dose of the thymidine analog $\mathrm{BrdU}(150 \mathrm{mg} / \mathrm{kg}$, i.p.) to CX3CR1-EGFP mice (P60; $n=6)$. Animals were euthanized at 1 , 3 , or $12 \mathrm{~h}$ or at 5 or $7 \mathrm{~d}$ after injection. At $3 \mathrm{~h}$ after BrdU injection, $\mathrm{BrdU}^{+}$cells were distributed along the SVZ/RMS, yet CX3CR1$\mathrm{EGFP}^{+}$cells were devoid of $\mathrm{DCX}^{+} / \mathrm{BrdU}^{+}$fragments (Fig. $5 d$,e, inset). The background signal, which is not related to DAPI ${ }^{+}$cell nuclei, was observed concomitant to the $\mathrm{HCl}$ denaturation used for BrdU immunolabeling and was not considered in this analysis. Interestingly, CX3CR1-EGFP ${ }^{+}$cells of the SVZ and RMS do not express TREM2 (triggering receptor expressed on myeloid cells 2), a receptor involved in the activation of microglial phagocytosis (Takahashi et al., 2005; Takahashi et al., 2007; Linnartz and Neumann, 2013; Fig. 5f,g).

A different picture emerged within the $\mathrm{OB}$, particularly in the granular layer, in which SVZ-generated neuroblasts are incorpo- 
a

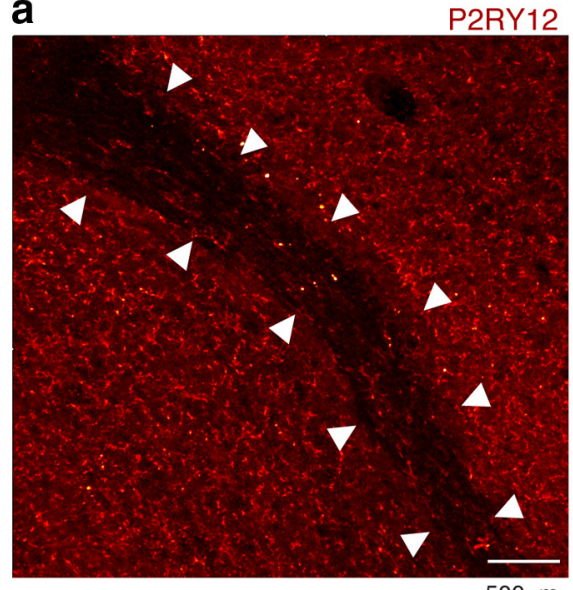

$500 u m$

d

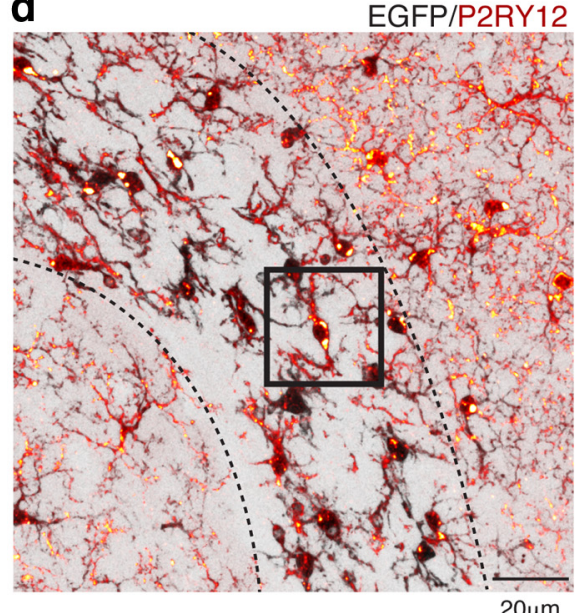

$20 \mathrm{um}$

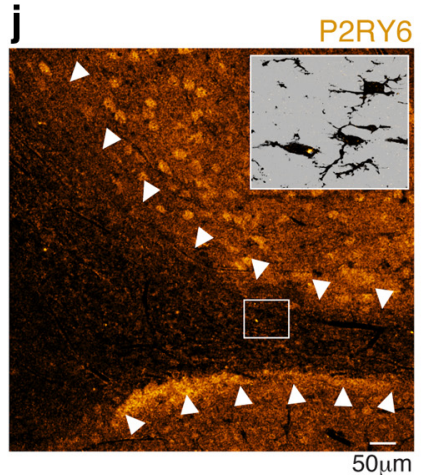

k b
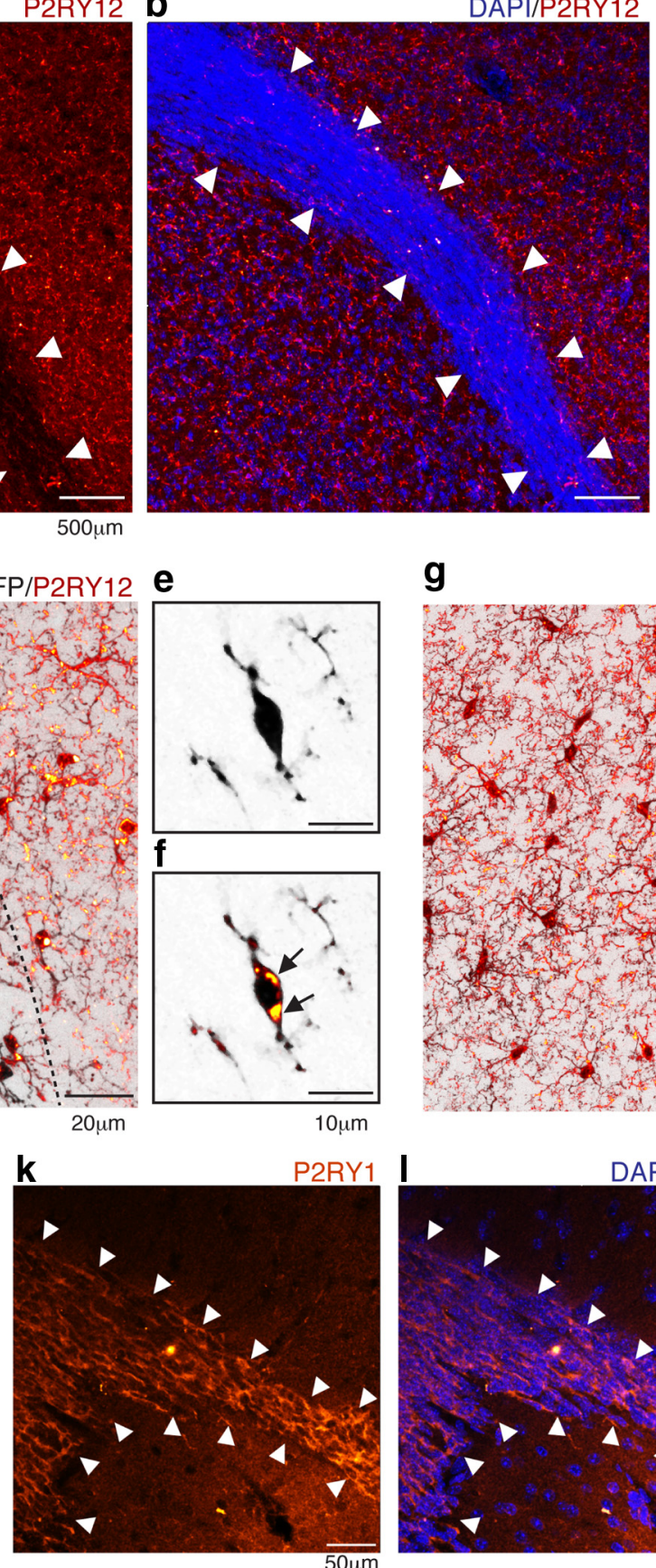

g

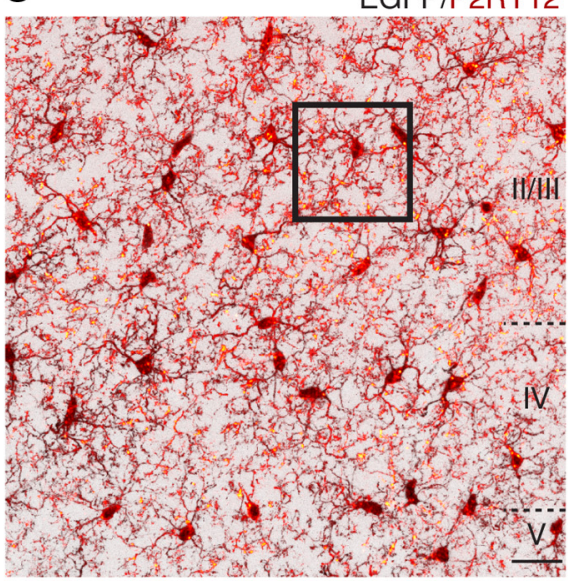

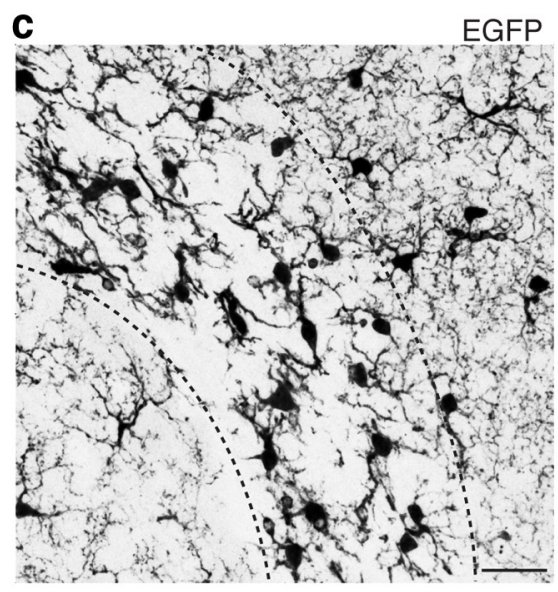

20um
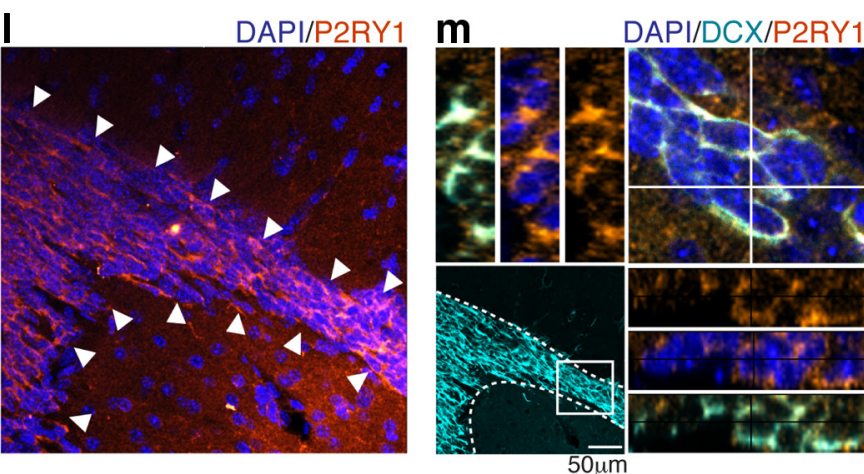

Figure 3. Purinergic receptor distribution along the SVZ/RMS pathway. P2RY12 (red) exhibits a markedly lower immunoreactivity within the SVZ/RMS borders (a, arrowheads). This region of lower P2RY12 expression corresponds to the dense cellular region (revealed by DAPI staining, blue, arrowheads) that characterizes the migratory pathway of SVZ-generated cells ( $\boldsymbol{b}$ ). Within the RMS, where less ramified CX3CR1-EGFP ${ }^{+}$cells are present (c, dashed line), confocal microscopy revealed that P2RY12 distribution was restricted to perinuclear region of CX3CR1-EGFP ${ }^{+}$cells (d). Orthogonal views demonstrated that RMS microglia are enriched on P2RY12 ( $\boldsymbol{e}, \boldsymbol{f}$, arrows). P2RY12 was conspicuously distributed in the cortical parenchyma $(\boldsymbol{g})$ and distributed along microglia processes (arrowheads) and cell soma (arrow) $(\boldsymbol{h}, \boldsymbol{i})$. Markedly lower immunoreactivity was also observed for P2RY6 (yellow) along the RMS, indicated by arrowheads (j), and very few XX3CR1$\mathrm{EGFP}^{+}$cells (black) were immunoreactive for P2RY6 (inset). In contrast, P2RY1 was highly expressed by the SVZ/RMS (orange, arrowheads, $\left.\boldsymbol{k}, \boldsymbol{I}\right)$. Within the migratory pathway, DCX ${ }^{+}$neuroblasts (cyan) expressed P2RY1, as observed by confocal microscopy analysis (m). Scale bars: $\boldsymbol{a}, \boldsymbol{b}, 500 \mu \mathrm{m} ; \boldsymbol{j}-\boldsymbol{l}, 50 \mu \mathrm{m} ; \boldsymbol{c}, \boldsymbol{d}, \boldsymbol{g}, 20 \mu \mathrm{m} ; \boldsymbol{e}, \boldsymbol{g}, \boldsymbol{h}, \boldsymbol{i}, 10 \mu \mathrm{m}$.

rated into the olfactory circuitry (Fig. 5h, inset). In the OB, appreciable numbers of $\mathrm{BrdU}^{+}$cells were first detected $7 \mathrm{~d}$ after a single BrdU pulse (Fig. 5h). However, whereas $>98 \%$ of all $\mathrm{BrdU}^{+}$cells in the SVZ/RMS were neural, and thus CX3CR1$\mathrm{EGFP}^{-},>50 \%$ of all CX3CR1-EGFP ${ }^{+}$microglia in the $\mathrm{OB}$ were $\mathrm{BrdU}^{+}$(Fig. 5c). Importantly, BrdU ${ }^{+}$fragments were located in the cytosol surrounding the DAPI-positive nuclei of Cx3CR1$\mathrm{EGFP}^{+}$microglia, suggesting that BrdU labeling do not reflect microglial cell division (Fig. 5i). Furthermore, within the OB, the CX3CR1-EGFP ${ }^{+} / \mathrm{BrdU}^{+}$cells displayed the amoeboid morphology of activated, phagocytic cells (Fig. 5i). In addition, in sharp contrast to SVZ, in the OB, we could detect TREM $2^{+}$cells (Fig. 5j). Notably, BrdU ${ }^{+}$fragments engulfed by CX3CR1$\mathrm{EGFP}^{+}$microglia in the OB were often associated with pyknotic cell nuclei, concurrent with TREM2 expression (Fig. 5k), suggesting that these are actively phagocytic microglial cells. Our obser- 


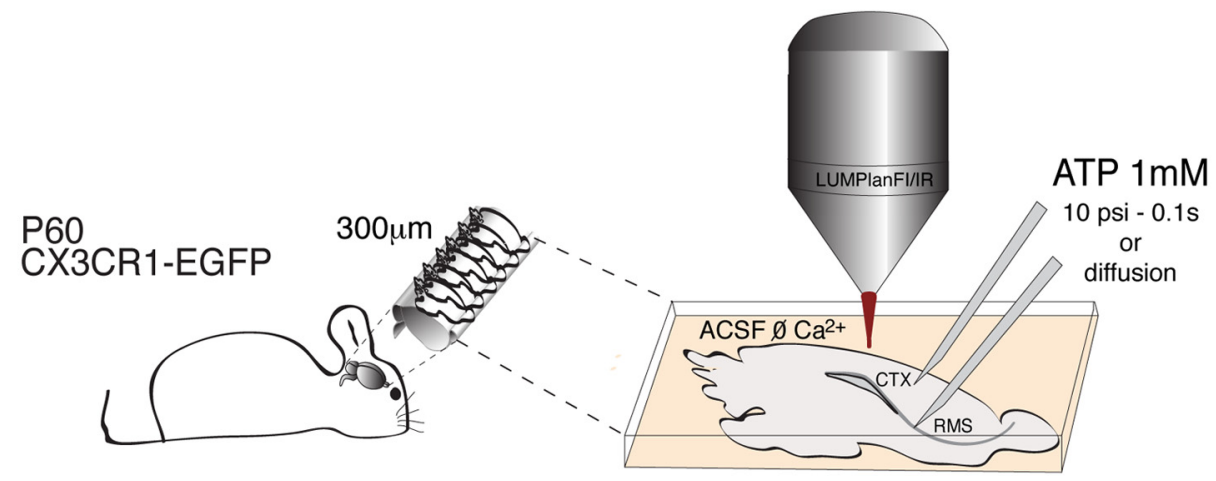

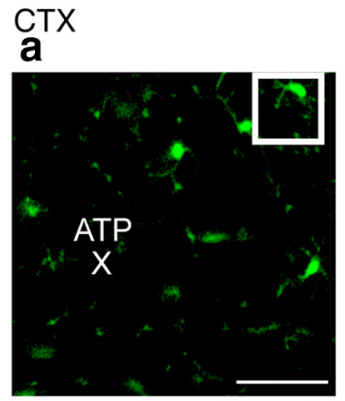

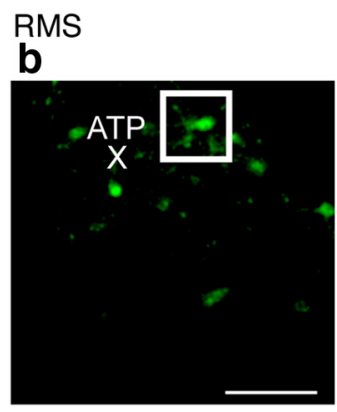

$50 \mu \mathrm{m}$

C

Variation of CX3CR1-EGFP ${ }^{+}$cells'

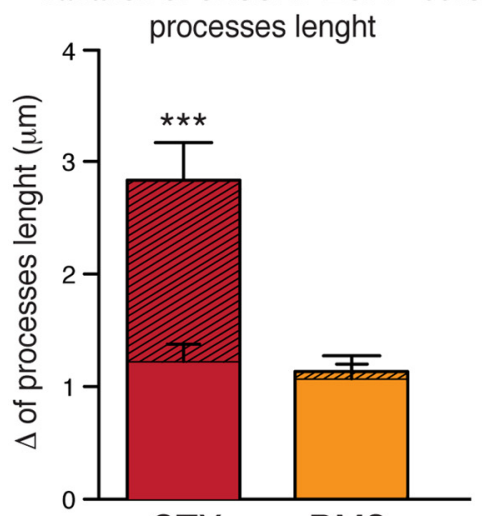

CTX

a'

b'
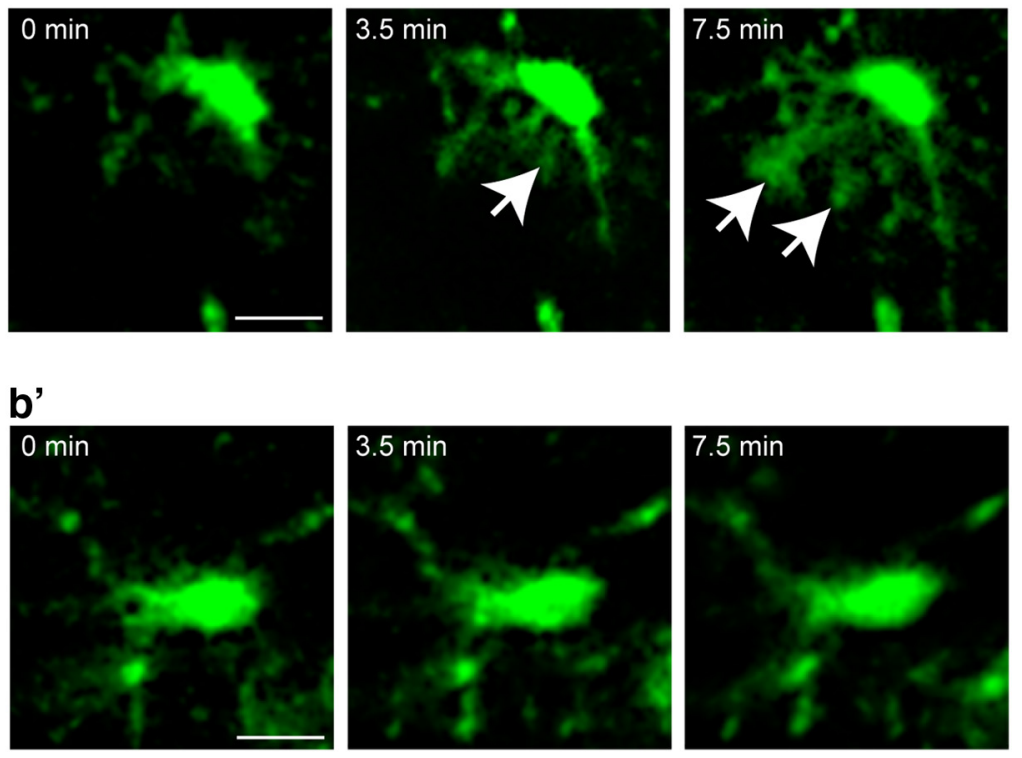

$10 \mu \mathrm{m}$

d

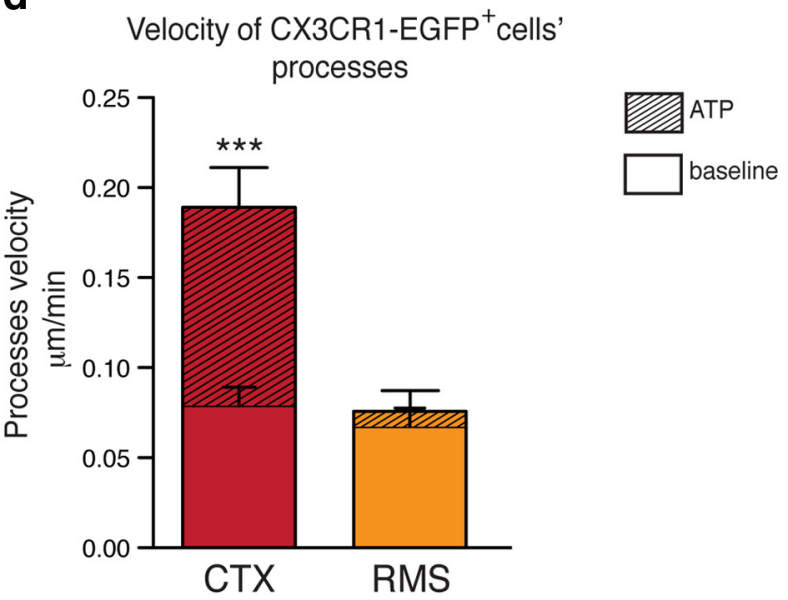

Figure 4. Differential expression of P2RY12 determines the attenuated responsiveness to ATP by RMS microglia cells. Slices $(300 \mu \mathrm{m})$ were obtained from vibratome sectioning of CX3CR1-EGFP mice (P60). During 2-photon analysis, slices were kept on ACSF $\varnothing \mathrm{Ca}^{2+}$ perfused with $5 \% \mathrm{CO}_{2} / 95 \% \mathrm{O}_{2}$ and, once ATP was applied, imaging scanning were performed every 15 s for a total interval of $15 \mathrm{~min}$. Glass pipettes (10-20 $\mu \mathrm{m}$ diameter) were positioned directly to cortical parenchyma or into the RMS and ATP (1 mM) was allowed to diffuse or applied with a $10 \mathrm{psi}$ pressure force for $0.1 \mathrm{~s}$ (schematic drawing). ATP release within the cortical parenchyma ( $\boldsymbol{a})$ triggers microglia (EGFP, green) processes extension ( $\boldsymbol{a}^{\prime}$, arrows). In contrast, when applied into the RMS, exogenous ATP does not trigger a robust recruitment of microglial processes $\left(\boldsymbol{b}, \boldsymbol{b}^{\prime}\right)$. Two-photon imaging showed that cortical microglial processes avidly extended toward the sites of ATP injection, whereas ATP-stimulated process movement by RMS microglia was barely appreciable (c) (baseline CTX: $1.23 \pm 0.15$; ATP CTX: $2.83 \pm 0.33$; baseline RMS: $1.05 \pm 0.13$; ATP RMS: $1.13 \pm 0.14 \mu$ m; mean \pm SEM; $p<0.0005$; Mann-Whitney test). We also compared the velocity of single processes in response to ATP in the (TX and RMS, and found a significant increase in cortical microglial process speed relative to that of the CX3CR1-EGFP ${ }^{+}$processes of RMS microglia, which were essentially unresponsive to ATP (baseline CTX: $0.08 \pm 0.01$; ATP CTX: $0.19 \pm 0.02$; baseline RMS: $0.07 \pm 0.01$; ATP RMS: $0.08 \pm 0.01 \mu \mathrm{m} / \mathrm{min}$; mean \pm SEM; $p<0.0005$; Mann-Whitney test; $\boldsymbol{d})$. Scale bars: $\boldsymbol{a}, \boldsymbol{b}, 50 \mu \mathrm{m} ; \boldsymbol{a}^{\prime}, \boldsymbol{b}^{\prime}, 10 \mu \mathrm{m}$. 
a
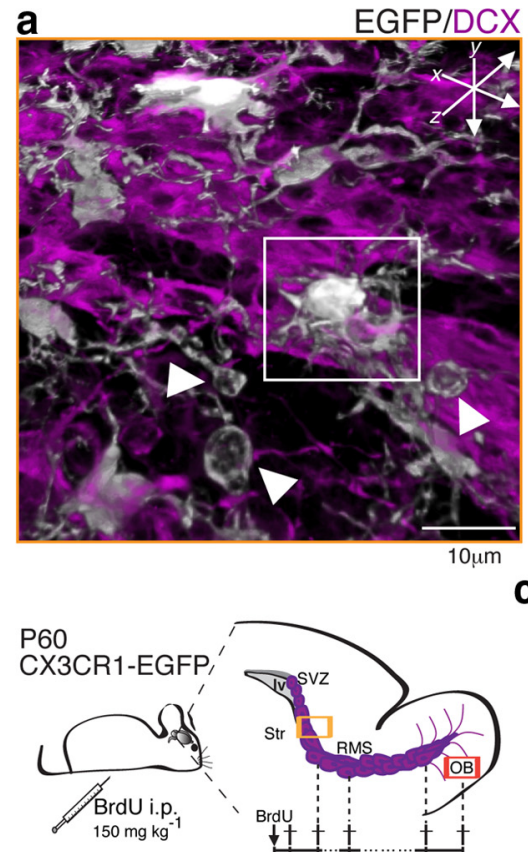

\section{b}

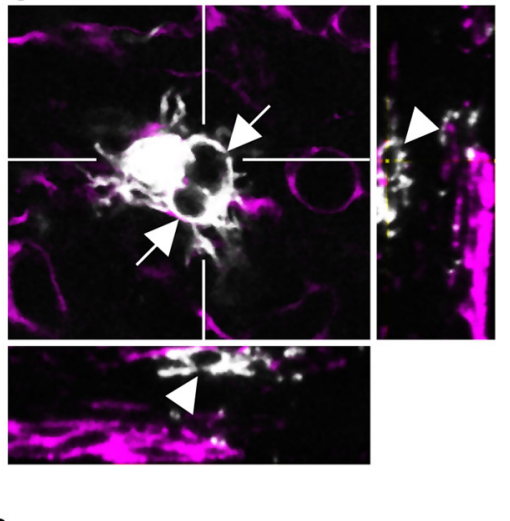

C

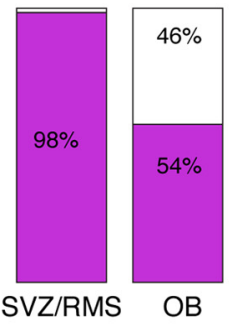

$\mathrm{BrdU}^{+} /$EGFP

$\mathrm{BrdU}^{+} / \mathrm{EGFP}^{+} \square$
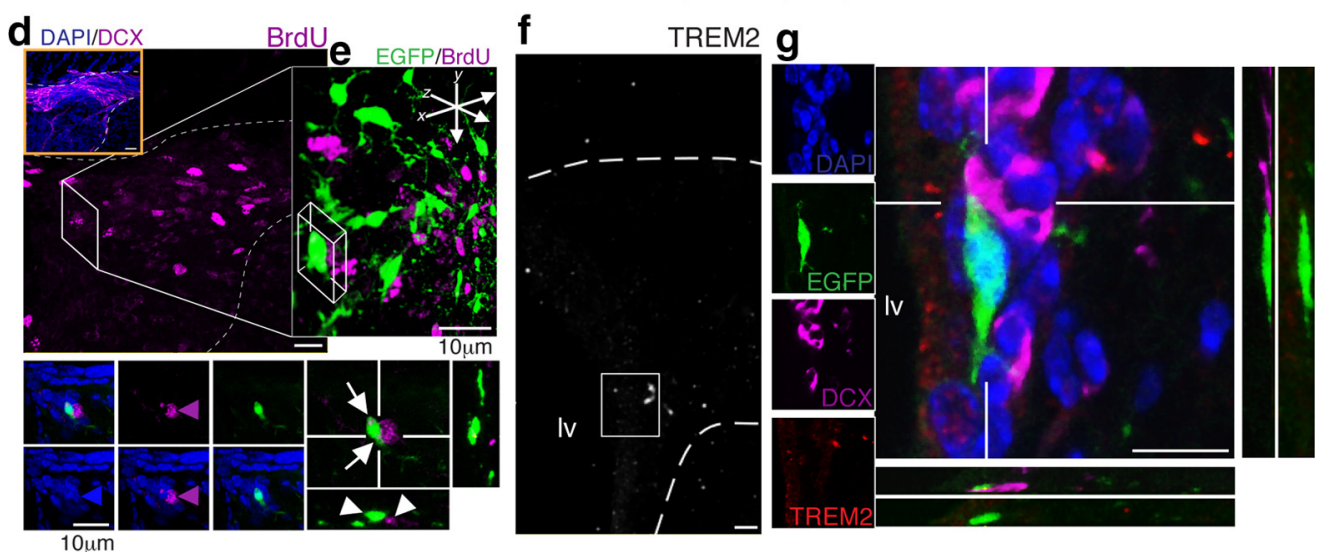

$\mathbf{h}_{\text {DAPIDCX }}$

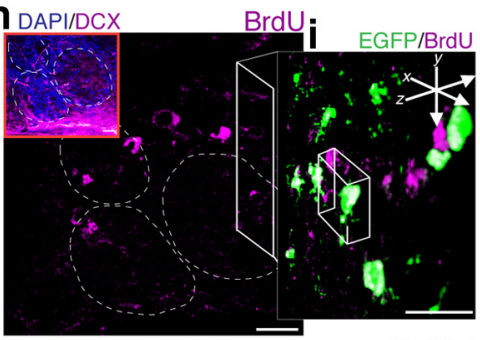

j TREM2 $\mathbf{k}$
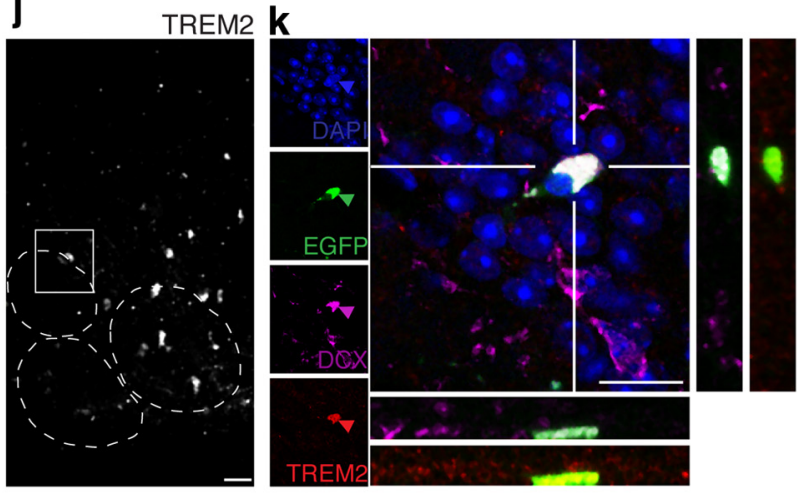

Figure 5. CX3CR1-EGFP ${ }^{+}$cells are widely distributed and intermingle with neuroblasts in the SVZ/RMS, yet microglial phagocytosis of neuronal precursors is uncommon. $\boldsymbol{a}$, In the RMS, $\mathrm{CX3CR1-EGFP}^{+}$cells (gray) intermingle with neuroblasts ( $\mathrm{DCX}{ }^{+}$, magenta). While some exhibit phagocytic bulges (white arrowheads), optical sectioning revealed that these bulges did not contain neuroblast fragments ( $\boldsymbol{b}$, white arrows and arrowheads). Newborn cells were also labeled by BrdU administration (150 $\mathrm{mg} \mathrm{kg}^{-1}$, i.p.). Brain sections were obtained from CX3CR1-EGFP mice (P60) killed 1, 3, $12 \mathrm{~h}$ and 5 and $7 \mathrm{~d}$ after a single dose of BrdU. $d, e, A t 3 \mathrm{~h}$, BrdU $^{+}$cells are distributed along a region that contains neuroblasts (DCX, magenta) surrounded by microglia (EGFP, green). Microglia processes contact some BrdU ${ }^{+}$cells; however, orthogonal views elucidate that CX3CR1-EGFP ${ }^{+}$cells are not engulfing neuroblasts (arrows and arrowheads, inset). $\boldsymbol{f}$, Immunolabeling for TREM2 (gray) in the SVZ. g, Within the SVZ, neuroblasts (DCX, magenta) are apposed to microglia (EGFP, green), but these cells do not express TREM2 (red), as shown in optical sections. Different observations were made in the $0 B$ within the glomerular layers $(\mathrm{gl}), 7 \mathrm{~d}$ after a single BrdU pulse. There, $\mathrm{CX3CR1-EGFP}{ }^{+}$cells were noted to have incorporated BrdU (h, $\boldsymbol{i}$. However, in these cells BrdU is located in the microglial cytoplasm, and associated with pyknotic cell nuclei, as may be inferred from the pattern of DAPI staining (blue, inset). $\boldsymbol{j}$, TREM2-immunoreactive cells are detected in the glomerular layer. $\boldsymbol{k}$, TREM2 is detected in those CX3CR1-EGFP ${ }^{+}$cells that have engulfed DCX ${ }^{+}$cells, which in turn have pyknotic nuclei (DAPI staining, blue arrowhead). Schematics represent parasagittal sections of analyzed areas, RMS (orange), and OB (light red). Iv, Lateral ventricle; Str, striatum. Scale bars: $10 \mu \mathrm{m}$. 

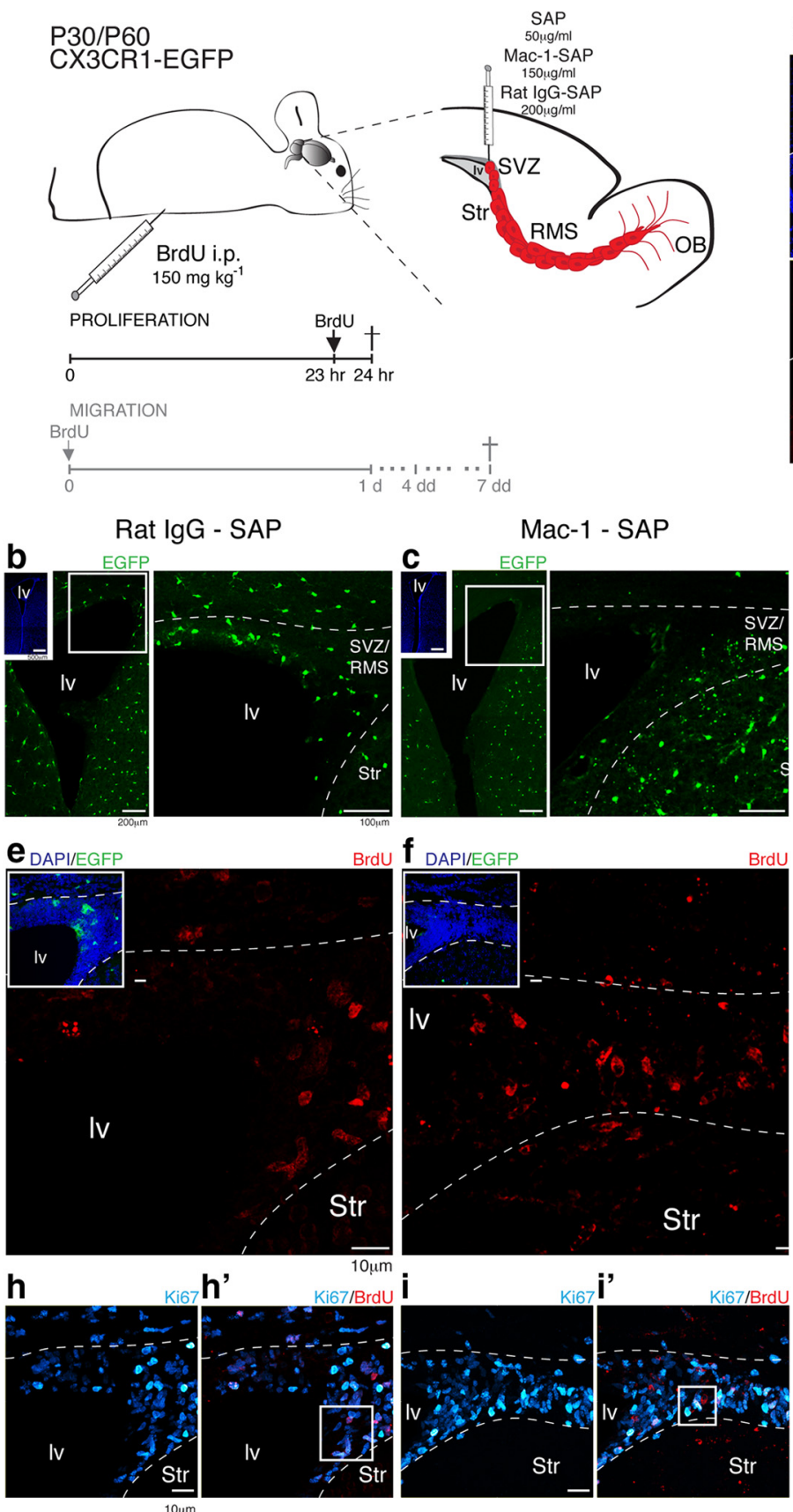

k

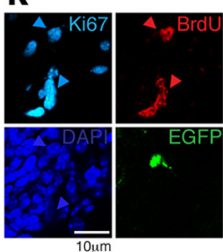

I

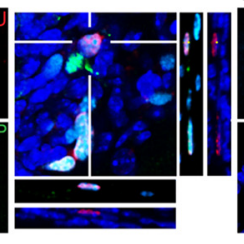

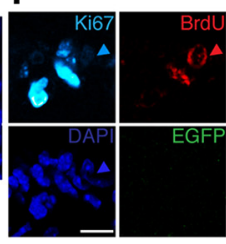

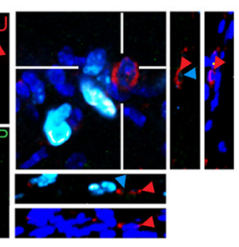

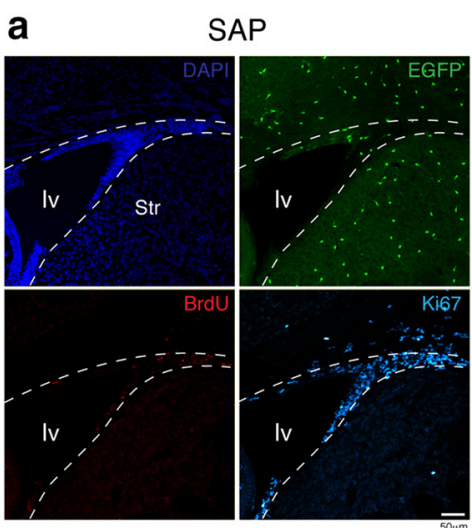

d CX3CR1-EGFP ${ }^{+}$cells in the SVZ 24 hrs after microglia depletion

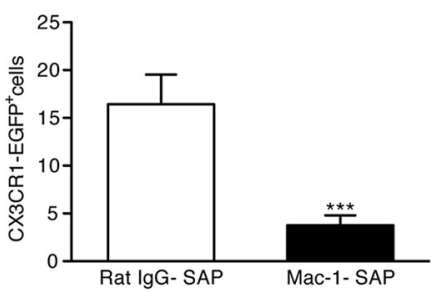

g

$\mathrm{BrdU}^{+}$cells in the SVZ $24 \mathrm{hrs}$ after microglia depletion
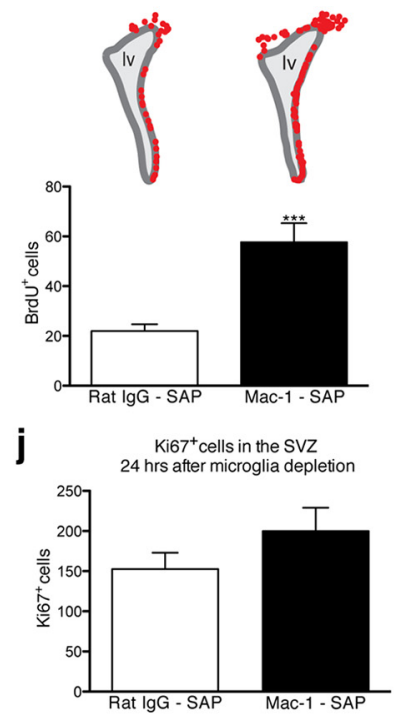

m

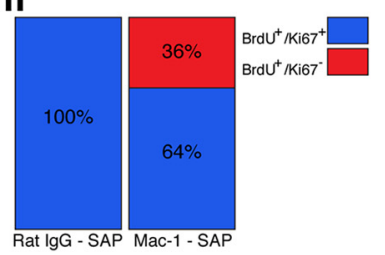

Figure 6. SVZ-microglia ablation triggered an accumulation of $\mathrm{BrdU}^{+}$cells, which did not correlate to an increase on cellular proliferative rates. The schematic illustrates a parasagittal brain section. Mice received injections of SAP ( $50 \mu \mathrm{g} / \mathrm{ml}$, i.v.), Mac-1-SAP ( $150 \mu \mathrm{g} / \mathrm{ml}$, i.v.), or rat lgG-SAP (200 $\mu \mathrm{g} / \mathrm{ml}$, i.v.). Injected CX3CR1-EGFP mice (P30-P60) also received a single dose of BrdU $\left(150 \mathrm{mg} \mathrm{kg}^{-1}\right.$, i.p.) $1 \mathrm{~h}$ before euthanasia. $\boldsymbol{a}$, SAP-injected animals showed CX3CR1-EGFP ${ }^{+}$cells (green) lining the lateral ventricles and BrdU ${ }^{+}$(red)/Ki67 ${ }^{+}$(cyan) cells $24 \mathrm{~h}$ after surgery, demonstrating that the SAP itself was not toxic. Within $24 \mathrm{~h}$, SVZ microglia (EGFP, green) was significantly reduced comparing control group animals (b) with Mac-1-SAP-treated mice (c) (rat IgG-SAP: $16 \pm 3$ cells; Mac-1-SAP: $4 \pm 1$ cells; mean \pm SEM; $p<0.0001 ; t$ test; $\boldsymbol{d})$. BrdU ${ }^{+}$cells in control mice $(\boldsymbol{e})$ were significantly lower compared with microglia-depleted mice $(\boldsymbol{f})$ (rat IgG-SAP: $22 \pm 3$ cells; Mac-1-SAP: $58 \pm 9$ cells; mean \pm SEM; $p<0.0001$; unpaired $t$ test; $\boldsymbol{g}$; schematic representation of coronal sections used for quantitative analysis). This difference in BrdU incorporation did not correlate with an increase in the number of Ki67 ${ }^{+}$cells, when we compared rat lgG-SAP $\left(\boldsymbol{h}, \boldsymbol{h}^{\prime}\right)$ and microglia-depleted mice $\left(\boldsymbol{I}, \boldsymbol{i}^{\prime}\right)($ rat lgG-SAP: $153 \pm 20$ cells; Mac-1-SAP: $200 \pm 29$ cells; mean \pm SEM; $p=0.1969$; Unpaired $t$ test; $j$ ). In control mice, all BrdU ${ }^{+}$cells observed also expressed Ki67 (k). In contrast, some BrdU ${ }^{+}$cells distributed in the SVZ of microglia-depleted mice exhibited pyknotic nuclei and did not express Ki67 (I). These BrdU ${ }^{+} / K_{i 67}{ }^{-}$cells corresponded to $36 \%$ of all BrdU ${ }^{+}$cells observed in Mac- $1-S A P$ injected mice $(\boldsymbol{m})$. Iv, Lateral ventricle; Str, striatum. Scale bars: $\boldsymbol{b}, \boldsymbol{c}$, insets, $500 \mu \mathrm{m} ; \boldsymbol{b}, \boldsymbol{c}, 200$ and $100 \mu \mathrm{m} ; \boldsymbol{a}, 50 \mu \mathrm{m} ; \boldsymbol{d}, \boldsymbol{e}, \boldsymbol{g}, \boldsymbol{h}, \boldsymbol{j}, \boldsymbol{k}, 10 \mu \mathrm{m}$. 
vations indicate that microglia within the SVZ and RMS are largely nonphagocytic and that phagocytosis of neuroblasts is thus a rare phenomenon within the neurogenic niche, yet a decidedly more frequent occurrence within the OB.

\section{Microglial cells residing in the SVZ/RMS pathway are crucial for neuroblast survival and migration}

To determine whether the specialized microglia that reside in the SVZ/RMS are critical for neurogenesis and/or for neuroblast migration, CX3CR1-EGFP mice were given intraventricular injections (i.v.t.) of SAP conjugated to monoclonal anti-CD11b (or Mac-1; Mac-1-SAP, $150 \mu \mathrm{g} / \mathrm{ml}$ ), to deplete microglia locally within the SVZ. Control animals were injected with rat Ig conjugated to SAP (rat IgG-SAP, $200 \mu \mathrm{g} / \mathrm{ml}$ ). In addition, another group of control animals received an injection of unconjugated SAP $(50 \mu \mathrm{g} / \mathrm{ml})$ as a control for nonspecific SAP toxicity. After $24 \mathrm{~h}$, animals injected with unconjugated SAP exhibited normally appearing Cx3CR1-EGFP ${ }^{+}$cells and dividing $\mathrm{BrdU}^{+} / \mathrm{Ki}^{+} 7^{+}$ cells, presumably neuroblasts, that were present along the lateral ventricle (Fig. 6a), suggesting that any direct toxicity of SAP is minor. Remarkably, we observed a significant decrease in the number of microglia in the SVZ in mice receiving Mac-1-SAP injection comparing the control group (rat IgG-SAP; Fig. 6b) with microglia-depleted animals (Fig. 6c) (Mac-1-SAP: $4 \pm 1$ cells; rat IgG-SAP: $16 \pm 3$ cells; mean \pm SEM; $n=9$ animals for each group in 3 independent experiments; $p<0.0001$; $t$ test; Fig. $6 d$ ). Therefore, Mac-1-SAP intraventricular injection resulted in a depletion of microglial cells restricted to the SVZ and a minor part of the overlying white matter, whereas injection of either rat IgG-SAP or SAP induced minimal changes.

To assess whether depletion of microglial cells affects proliferative rates in the SVZ, we administered a BrdU pulse (150 mg/ $\mathrm{kg}$, i.p.) $1 \mathrm{~h}$ before euthanasia and $24 \mathrm{~h}$ after microglia ablation. Interestingly, compared with control animals (showed in Fig. 6e), the number of $\mathrm{BrdU}^{+}$cells in the SVZ was significantly increased in microglia-depleted mice (Fig. $6 f$; rat IgG-SAP: $22 \pm 3$ cells; Mac-1-SAP: $58 \pm 9$ cells; mean \pm SEM; $n=9$ animals for each group in 3 independent experiments; $p<0.0001$; unpaired $t$ test; Fig. $6 g$ ). Intriguingly, this difference in $\mathrm{BrdU}^{+}$cells did not correlate with an increase in the number of $\mathrm{Ki}^{+} 7^{+}$cells when we compared control animals (Fig. 6h, $h^{\prime}$ ) and microglia-depleted mice (Fig. 6i, $\left.i^{\prime}\right)($ IgG -SAP: $153 \pm 20$ cells; Mac-1-SAP: $200 \pm 29$ cells; mean \pm SEM; $n=9$ animals for each group in 3 independent experiments; $p=0.1969$; unpaired $t$ test; Fig. $6 j$ ). The major difference was that while the majority of $\mathrm{BrdU}^{+}$cells also express Ki67 in control mice (Fig. $6 k$ ), most of the $\mathrm{BrdU}^{+}$cells in the SVZ of microglia-depleted mice exhibited pyknotic cell nuclei and did not express Ki67 (Fig. 6l,m). These observations suggest that microglial ablation directly affected neuroblast survival and migration. In support of this conclusion, in control animals, migrating neuroblasts were distributed in well arranged chains (Fig. 7a) that contained dividing cells $\left(\mathrm{BrdU}^{+}\right.$; Fig. $\left.7 b\right)$. In contrast, the unidirectionality of these migratory chains of $\mathrm{DCX}^{+}$cells was disrupted in Mac-1-SAP-injected animals and accompanied by the superposition of their cell nuclei (Fig. 7c). In addition, $\mathrm{BrdU}^{+}$ fragments containing pyknotic nuclei were present within the migratory chains of microglial-depleted mice (Fig. $7 d$ ). Together, these observations suggest that microglia in the SVZ and RMS promote neuroblast cell survival along the migratory pathway to the $\mathrm{OB}$.

To further investigate this concept, we next investigated whether the observed disruption of neuroblast chains was associated with a reduction in $\mathrm{BrdU}^{+}$neuroblast recruitment to the OB. To test this hypothesis, we analyzed CX3CR1-EGFP mice
( $n=9$ animals/group, 3 independent experiments) that were injected with either rat IgG-SAP or Mac-1-SAP $(200 \mu \mathrm{g} / \mu \mathrm{l}$ and $150 \mu \mathrm{g} / \mu \mathrm{l}$, i.v.t., respectively) and received a dose of BrdU (150 $\mathrm{mg} / \mathrm{kg}$, i.p.) at the end of the surgery. Analysis of $\mathrm{BrdU}^{+}$cell distribution $7 \mathrm{~d}$ after microglial depletion showed that very few neuroblasts were detected in the anterior portion of the SVZ in control mice (Fig. $7 f$ ), whereas a large number of BrdU fragments remained in the SVZ of microglia-depleted animals (Fig. 7i) (SVZ: rat IgG-SAP: $1 \pm 0.4$ cell; Mac-1-SAP: $36 \pm 9$ cells; mean \pm SEM; $p=0.0018$, unpaired $t$ test; Fig. $7 e$ ). In control animals, CX3CR1-EGFP ${ }^{+}$cells that intermingled with $\mathrm{BrdU}^{+}$ neuroblasts were evident within the RMS (Fig. $7 g$ ), whereas BrdU fragments accumulated in this region in microglia-depleted mice (Fig. 7j) (RMS: rat IgG-SAP: $14 \pm 2$ cells; Mac-1-SAP: $26 \pm 6$ cells; mean \pm SEM; $p=0.0605$, unpaired $t$ test; Fig. 7e). Significantly fewer $\mathrm{BrdU}^{+}$cells reached the $\mathrm{OB}$ in microglia-depleted mice (Fig. 7k) compared with control animals (Fig. 7h) (OB: rat IgG-SAP: $58 \pm 6$ cells; Mac-1-SAP: $14 \pm 3$ cells; mean \pm SEM; $p<0.00001$; unpaired $t$ test) (Fig. 7e). Therefore, microglial depletion impaired the survival and migration of SVZ-generated neuroblasts.

\section{Discussion}

Microglial cells are the primary immune effectors in CNS. However, recent studies suggest that microglia also participate in shaping CNS networks during development. For example, microglia provide trophic support and play a key role in synaptic pruning in early development (Tremblay et al., 2010; Kettenmann et al., 2011; Paolicelli et al., 2011; Tremblay et al., 2011; Schafer et al., 2012; Kettenmann et al., 2013; Schafer et al., 2013; Ueno et al., 2013). Microglia are also involved in the continuous shaping of the adult hippocampus, a neurogenic niche that persists throughout the mammalian lifespan (Altman and Das, 1965; Eriksson et al., 1998; Roy et al., 2000; Deng et al., 2010). Microglia in the subgranular zone of the hippocampus phagocytose apoptotic newborn neuroblasts and have therefore been implicated in hippocampal-dependent learning and memory processing ( $\mathrm{Si}$ erra et al., 2010).

In contrast to the hippocampus, SVZ-generated neuroblasts migrate long distances through the RMS to the OB (Lois et al., 1996), where they differentiate into GABAergic interneurons and, to a smaller extent, into glutamatergic cells (Zhao et al., 2008; Brill et al., 2009; Sequerra et al., 2010). In addition to the key role of SVZ-generated neuroblasts in olfaction, this neurogenic zone constitute a potential source of endogenous progenitors for cell therapy because they can be recruited and functionally integrated into extant adult striatal circuits (Benraiss et al., 2012; Benraiss et al., 2013). It is therefore of urgent interest to determine if microglial cells influence SVZ neuroblast proliferation and migration. Our present study reveals that a distinct microglial population resides in the SVZ/RMS, and that the presence of microglia is critical for both neuronal precursor survival and migration.

Limited information is available regarding the distribution and functional heterogeneity of microglia in the SVZ (Lawson et al., 1990; Lawson et al., 1992; Caggiano and Brunjes, 1993; Goings et al., 2006). A previous study examining the cellular composition of SVZ reported that microglia are present in low numbers (Doetsch et al., 1997). Our analysis, using the CX3CR1-EGFP reporter mouse rather than functionally modulated antigenic markers, showed that the density of microglia in the SVZ, RMS, and $\mathrm{OB}$ regions is comparable to the density of microglia in cortex (Fig. 1g). The distinct morphology of microglia residing in the 

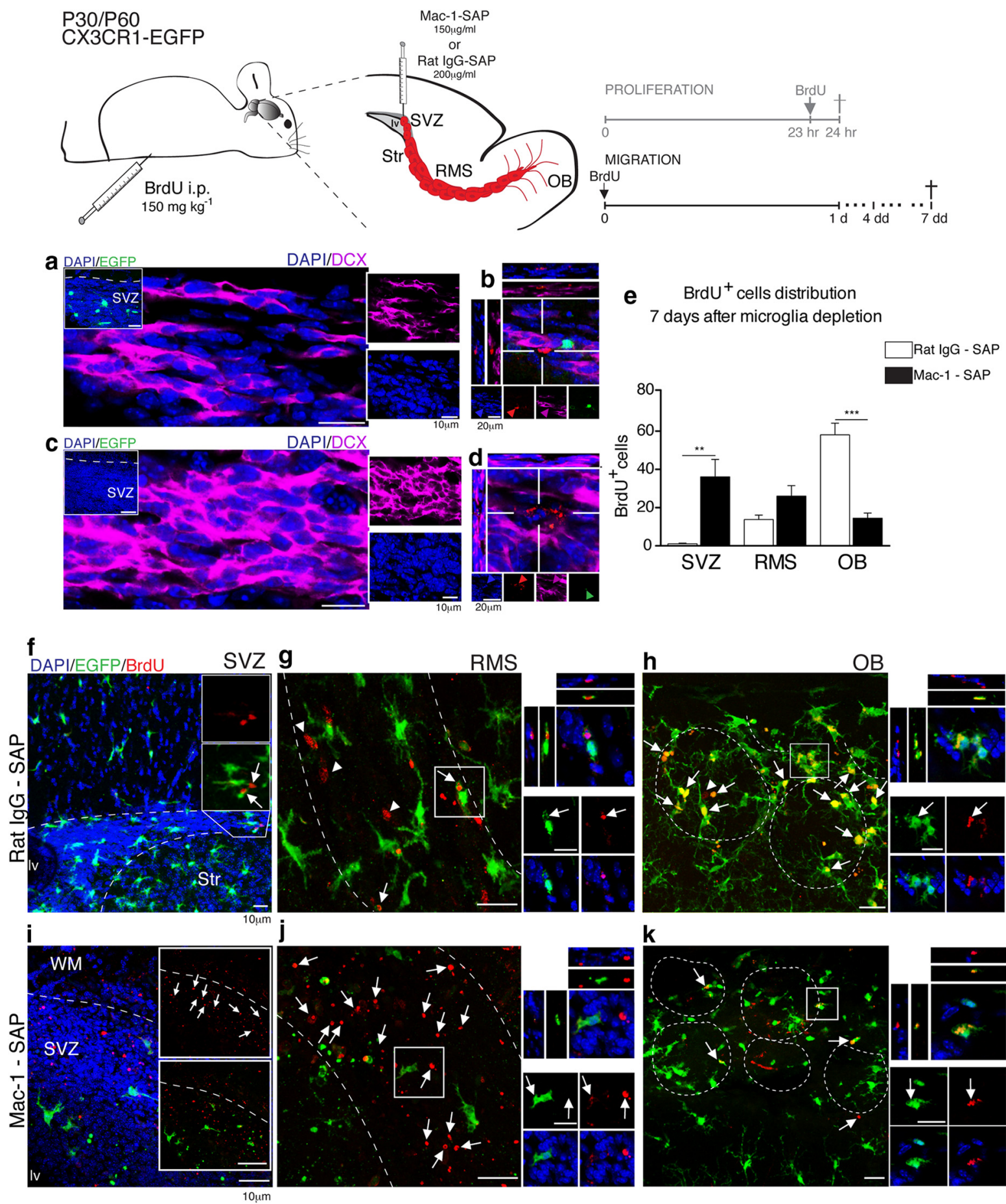

Figure 7. SVZ-microglia depletion disrupts neuroblast migration. Illustrative scheme of a parasagittal brain section of mice that received intravenous injections of Mac-1-SAP or rat $\mathrm{IgG}-\mathrm{SAP}$. At the end of the surgery, BrdU (150 $\mathrm{mg} \mathrm{kg}^{-1}$, i.p.) was administered and neuroblast distribution was assessed within a $4-7 \mathrm{~d}$ interval. $\boldsymbol{a}$, In control mice, microglia (EGFP, green) are present in the SVZ (inset) and intermingle with well arranged chains of migrating neuroblasts (DCX, magenta). Dividing cells (BrdU ${ }^{+}$, red) were observed along the migratory chains $(\boldsymbol{b}) . \boldsymbol{c}$, In contrast, in microglia-depleted mice, CX3CR1-EGFP ${ }^{+}$cells were absent (inset), and DCX ${ }^{+}$cell distribution was disrupted. This led to a loss of the neuroblast chain unidirectionality, which was associated with a superposition of cell nuclei. Furthermore, the majority of BrdU fragments were associated with pyknotic nuclei (d). After $7 \mathrm{~d}$, relatively few $\mathrm{BrdU}^{+}$cells were observed in the most anterior portion of SVZ of control animals, abutting the RMS ( $\boldsymbol{f}$, white arrows). This pattern differed significantly from that of Mac-1-SAP-injected mice (IgG-SAP: $1 \pm 0.4$ cell; Mac-1-SAP: $36 \pm 9$ cells; mean \pm SEM; $p=0.0018$; unpaired $t$ test; $\boldsymbol{e}$ ), in which the SVZ contained a larger number of BrdU fragments (i, white arrows). Within the RMS of control animals, we noted BrdU ${ }^{+}$neuroblasts ( $g$, white arrowheads) and only few BrdU ${ }^{+}$fragments (indicated by white arrows, depicted in optical section). In contrast, in microglia-depleted mice, we observed an accumulation of $\mathrm{BrdU}^{+}$fragments ( $\boldsymbol{j}$, white arrows), that were not engulfed by microglia (white arrows in the inset). However, the number of BrdU ${ }^{+}$cells and fragments were not significantly different $(\boldsymbol{g})$ (rat lgG-SAP: $14 \pm 2$ cells; Mac-1-SAP: $26 \pm 6$ cells; mean \pm SEM; $p=0.0605$; unpaired $t$ test) $(\boldsymbol{e})$. Within the glomerular layers, we observed a decrease in the number of BrdU ${ }^{+}$cells that reached these layers in Mac-1-SAP injected mice ( $\boldsymbol{k}$, white arrows), that proved statistically different from control animals $(\boldsymbol{h})$, in which we observed BrdU ${ }^{+} / \mathrm{EGFP}^{+}$cells (white arrows) and few BrdU ${ }^{+} / \mathrm{EGFP}^{-}$cells (white arrowhead) (rat IgG-SAP: $58 \pm 6$ cells; Mac-1-SAP: $14 \pm 3$ cells; mean \pm SEM; $p<0.00001$; unpaired $t$ test) (e). Iv, Lateral ventricle; Str, striatum; WM, white matter. Scale bars: $10 \mu \mathrm{m}$. 
SVZ and RMS (Fig. 1b,d) suggests that these microglia may serve very different functions than their cortical counterparts.

Based on their distinct morphology and expression of pSTAT6 (Fig. 2d,e), we believe that microglia within the SVZ are of an alternatively activated phenotype. This phenotype correlates functionally by its expression of STAT6-regulated genes, which are activated by the cytokines IL-4, IL-10, and IL-13 (Biswas and Mantovani, 2010; Boche et al., 2013). Accordingly, the profile of released cytokines by acutely dissociated SVZ cells showed that IL-4 and IL-10 were present in the culture media (Fig. 2b). In vitro experiments have shown that conditioned media from microglial cultures promote SVZ neuroblast migration and neuronal differentiation (Aarum et al., 2003) and that microglia activated by IL- 4 can promote neurodendrogenesis and oligodendrogenesis from adult stem cells (Butovsky et al., 2006). We also detected IL-6 in the culture media from isolated SVZ cells (Fig. 2b). Although this cytokine can act as a pro-inflammatory mediator (Scheller et al., 2011), it has also been shown to enhance SVZ progenitor division and self-renewal in vitro and may be a critical driver of neural progenitor expansion in rodents (Covey et al., 2011).

To our knowledge, our observations provide the first in vivo evidence that SVZ/RMS microglia are critical participants in neuronal recruitment to the adult $\mathrm{OB}$. Interestingly, depletion of microglia in the SVZ was linked to a marked reduction in neuroblasts reaching the $\mathrm{OB}$ and the concomitant accumulation of $\mathrm{BrdU}^{+}$cells in the SVZ/RMS. The increase in the number of $\mathrm{BrdU}^{+}$cells in the SVZ (Fig. 6e,f) might have reflected an increase in the mitotic rate of neuroblasts triggered by cytokines released from the microglia in response to SAP-mediated depletion or by other glia in response to microglial death. Alternatively, the increase in the number of $\mathrm{SVZ} \mathrm{BrdU}^{+}$cells might have reflected the impaired migration of newly generated neuroblasts occasioned by the lack of microglial support. The lack of microglial support was clearly associated with apoptotic cell death based on the pyknotic cell nuclei and lack of concurrent Ki67 expression by BrdU ${ }^{+}$cells in the SVZ/RMS (Fig. $6 h^{\prime}, k$ ). Moreover, $\mathrm{BrdU}^{+}$fragments could also be found along the entire SVZ/ RMS pathway in microglia-depleted mice, suggesting that neuroblasts need microglial support for their migration process toward the OB (Fig. 7i-k). Consistent with this hypothesis, we found that the consequence of microglia depletion was that the number of $\mathrm{BrdU}^{+}$cells that reached the OB layers was sharply reduced (Fig. 7e). Our observations suggest that microglia residing in the SVZ/RMS regions are critical for neuroblast survival and migration, possibly as a consequence of their release of the cytokines IL-4, IL-6, and IL-10.

It is also important to note that microglia-mediated phagocytosis of neuroblasts was a rare phenomenon along the SVZ/RMS migratory pathway (Fig. 5a-c) and, accordingly, markers of activated microglia such as TREM2 (Fig. 5f,g) and CD68 (Fig. $1 k$ ) were not detectable in the SVZ/RMS. In contrast, within the OB layers, where interneurons are continuously replaced by SVZgenerated precursors, microglia exhibited overt and robust phagocytosis (Fig. $5 h, i$ ), as reflected by their amoeboid morphology and TREM2 immunoreactivity (Fig. $5 i-k$ ). Therefore, microglia in the neurogenic areas of SVZ/RMS are unique and specialized to support neural precursor proliferation and migration along significant distances toward their final destination (Menezes et al., 1995; Zhao et al., 2006; Platel et al., 2008). We propose that the efficiency of replenishing neurons in the olfactory system would be compromised if microglia-mediated phagocytosis were not suppressed along the migratory pathway.
Microglia can undergo rapid phenotypic changes in response to receptor activation or environmental changes, which include alterations in their fine structure, antigenicity, process motility, phagocytosis, and cytokine release (Jordan and Thomas, 1988; Kettenmann et al., 2011). We speculate that the microglial phenotype that we have identified in the SVZ/RMS is specialized not only to provide trophic support, but also to prevent purinergic signaling from triggering premature phagocytosis of the migrating neuroblasts. Microglia residing along the SVZ/RMS were small cells with few, unbranched processes (Fig. $3 c$ ) that manifested little P2RY12 expression (Fig. 3a,b) and exhibited little process motility in response to ATP (Fig. $\left.4 b, b^{\prime}\right)$. However, based on the high level of the ATP-processing ectoenzyme NTDPase-2 in neurogenic zones (Braun et al., 2003), together with the P2RY1-dependent mitogenic actions of ATP on neural stem and progenitor cells (Mishra et al., 2006; Lin et al., 2007), as well as the importance of P2RY1 for guiding neuroblast migration (Cao et al., 2013), it has been speculated that purine signaling is highly active in the SVZ and RMS). The striking low levels of purine receptors in SVZ/RMS microglia may thus comprise a regional specialization of microglia that allows them to avoid inappropriate activation in response to locally active purinergic mitogens, which might otherwise result in the undesired phagocytosis of neuroblasts before their reaching the $\mathrm{OB}$.

Our results suggest the existence of a uniquely specialized microglial phenotype residing within the adult SVZ/RMS. These cells may play an important role in the survival and migration of newly generated neurons toward a destination that is particularly susceptible to age- and neurodegeneration-related impairment. Indeed, although olfactory function diminishes in neurodegenerative disorders such as Alzheimer's disease, microglial activation may restore olfactory function in animal models of Alzheimer's (Zotova et al., 2011). These findings may thus offer a new cellular target, the microglial cell, for therapeutic strategies designed to enhance neuronal recruitment from endogenous progenitor cells of the adult brain.

\section{References}

Aarum J, Sandberg K, Haeberlein SL, Persson MA (2003) Migration and differentiation of neural precursor cells can be directed by microglia. Proc Natl Acad Sci U S A 100:15983-15988. CrossRef Medline

Alliot F, Godin I, Pessac B (1999) Microglia derive from progenitors, originating from the yolk sac, and which proliferate in the brain. Brain Res Dev Brain Res 117:145-152. CrossRef Medline

Altman J, Das GD (1965) Autoradiographic and histological evidence of postnatal hippocampal neurogenesis in rats. J Comp Neurol 124:319335. CrossRef Medline

Battista D, Ferrari CC, Gage FH, Pitossi FJ (2006) Neurogenic niche modulation by activated microglia: transforming growth factor beta increases neurogenesis in the adult dentate gyrus. Eur J Neurosci 23:83-93. CrossRef Medline

Benraiss A, Bruel-Jungerman E, Lu G, Economides AN, Davidson B, Goldman SA (2012) Sustained induction of neuronal addition to the adult rat neostriatum by AAV4-delivered noggin and BDNF. Gene Ther 19:483493. CrossRef Medline

Benraiss A, Toner MJ, Xu Q, Bruel-Jungerman E, Rogers EH, Wang F, Economides AN, Davidson BL, Kageyama R, Nedergaard M, Goldman SA (2013) Sustained mobilization of endogenous neural progenitors delays disease progression in a transgenic model of Huntington's disease. Cell Stem Cell 12:787-799. CrossRef Medline

Biswas SK, Mantovani A (2010) Macrophage plasticity and interaction with lymphocyte subsets: cancer as a paradigm. Nat Immunol 11:889-896. CrossRef Medline

Boche D, Perry VH, Nicoll JA (2013) Review: activation patterns of microglia and their identification in the human brain. Neuropathol Appl Neurobiol 39:3-18. CrossRef Medline

Braun N, Sévigny J, Mishra SK, Robson SC, Barth SW, Gerstberger R, Ham- 
mer K, Zimmermann H (2003) Expression of the ecto-ATPase NTPDase2 in the germinal zones of the developing and adult rat brain. Eur J Neurosci 17:1355-1364. CrossRef Medline

Brill MS, Ninkovic J, Winpenny E, Hodge RD, Ozen I, Yang R, Lepier A, Gascón S, Erdelyi F, Szabo G, Parras C, Guillemot F, Frotscher M, Berninger B, Hevner RF, Raineteau O, Götz M (2009) Adult generation of glutamatergic olfactory bulb interneurons. Nat Neurosci 12:15241533. CrossRef Medline

Butovsky O, Ziv Y, Schwartz A, Landa G, Talpalar AE, Pluchino S, Martino G, Schwartz M (2006) Microglia activated by IL-4 or IFN-gamma differentially induce neurogenesis and oligodendrogenesis from adult stem/progenitor cells. Mol Cell Neurosci 31:149-160. CrossRef Medline

Caggiano AO, Brunjes PC (1993) Microglia and the developing olfactory bulb. Neuroscience 52:717-724. CrossRef Medline

Cao L, Wei D, Reid B, Zhao S, Pu J, Pan T, Yamoah E, Zhao M (2013) Endogenous electric currents might guide rostral migration of neuroblasts. EMBO Rep 14:184-190. CrossRef Medline

Chao CC, Molitor TW, Hu S (1993) Neuroprotective role of IL-4 against activated microglia. J Immunol 151:1473-1481. Medline

Covey MV, Loporchio D, Buono KD, Levison SW (2011) Opposite effect of inflammation on subventricular zone versus hippocampal precursors in brain injury. Ann Neurol 70:616-626. CrossRef Medline

Deng W, Aimone JB, Gage FH (2010) New neurons and new memories: how does adult hippocampal neurogenesis affect learning and memory? Nat Rev Neurosci 11:339-350. CrossRef Medline

Doetsch F, García-Verdugo JM, Alvarez-Buylla A (1997) Cellular composition and three-dimensional organization of the subventricular germinal zone in the adult mammalian brain. J Neurosci 17:5046-5061. Medline

Eriksson PS, Perfilieva E, Björk-Eriksson T, Alborn AM, Nordborg C, Peterson DA, Gage FH (1998) Neurogenesis in the adult human hippocampus. Nat Med 4:1313-1317. CrossRef Medline

Ginhoux F, Greter M, Leboeuf M, Nandi S, See P, Gokhan S, Mehler MF, Conway SJ, Ng LG, Stanley ER, Samokhvalov IM, Merad M (2010) Fate mapping analysis reveals that adult microglia derive from primitive macrophages. Science 330:841-845. CrossRef Medline

Ginhoux F, Lim S, Hoeffel G, Low D, Huber T (2013) Origin and differentiation of microglia. Front Cell Neurosci 7:45. Medline

Goings GE, Kozlowski DA, Szele FG (2006) Differential activation of microglia in neurogenic versus non-neurogenic regions of the forebrain. Glia 54:329-342. CrossRef Medline

Gregersen R, Lambertsen K, Finsen B (2000) Microglia and macrophages are the major source of tumor necrosis factor in permanent middle cerebral artery occlusion in mice. J Cereb Blood Flow Metab 20:53-65. CrossRef Medline

Haynes SE, Hollopeter G, Yang G, Kurpius D, Dailey ME, Gan WB, Julius D (2006) The P2Y12 receptor regulates microglial activation by extracellular nucleotides. Nat Neurosci 9:1512-1519. CrossRef Medline

Jordan FL, Thomas WE (1988) Brain macrophages: questions of origin and interrelationship. Brain Res 472:165-178. Medline

Jung S, Aliberti J, Graemmel P, Sunshine MJ, Kreutzberg GW, Sher A, Littman DR (2000) Analysis of fractalkine receptor CX(3)CR1 function by targeted deletion and green fluorescent protein reporter gene insertion. Mol Cell Biol 20:4106-4114. CrossRef Medline

Kettenmann H, Hanisch UK, Noda M, Verkhratsky A (2011) Physiology of microglia. Physiol Rev 91:461-553. CrossRef Medline

Kettenmann H, Kirchhoff F, Verkhratsky A (2013) Microglia: new roles for the synaptic stripper. Neuron 77:10-18. CrossRef Medline

Koizumi S, Shigemoto-Mogami Y, Nasu-Tada K, Shinozaki Y, Ohsawa K, Tsuda M, Joshi BV, Jacobson KA, Kohsaka S, Inoue K (2007) UDP acting at P2Y6 receptors is a mediator of microglial phagocytosis. Nature 446:1091-1095. CrossRef Medline

Lawson LJ, Perry VH, Dri P, Gordon S (1990) Heterogeneity in the distribution and morphology of microglia in the normal adult mouse brain. Neuroscience 39:151-170. CrossRef Medline

Lawson LJ, Perry VH, Gordon S (1992) Turnover of resident microglia in the normal adult mouse brain. Neuroscience 48:405-415. CrossRef Medline

Lin JH, Takano T, Arcuino G, Wang X, Hu F, Darzynkiewicz Z, Nunes M, Goldman SA, Nedergaard M (2007) Purinergic signaling regulates neural progenitor cell expansion and neurogenesis. Dev Biol 302:356-366. CrossRef Medline

Linnartz B, Neumann H (2013) Microglial activatory (immunoreceptor tyrosine-based activation motif)- and inhibitory (immunoreceptor tyrosine-based inhibition motif)-signaling receptors for recognition of the neuronal glycocalyx. Glia 61:37-46. CrossRef Medline

Liu JS, Amaral TD, Brosnan CF, Lee SC (1998) IFNs are critical regulators of IL-1 receptor antagonist and IL-1 expression in human microglia. J Immunol 161:1989-1996. Medline

Lois C, Alvarez-Buylla A (1994) Long-distance neuronal migration in the adult mammalian brain. Science 264:1145-1148. CrossRef Medline

Lois C, García-Verdugo JM, Alvarez-Buylla A (1996) Chain migration of neuronal precursors. Science 271:978-981. CrossRef Medline

Marín-Teva JL, Dusart I, Colin C, Gervais A, van Rooijen N, Mallat M (2004) Microglia promote the death of developing Purkinje cells. Neuron 41: 535-547. CrossRef Medline

Menezes JR, Smith CM, Nelson KC, Luskin MB (1995) The division of neuronal progenitor cells during migration in the neonatal mammalian forebrain. Mol Cell Neurosci 6:496-508. CrossRef Medline

Mishra SK, Braun N, Shukla V, Füllgrabe M, Schomerus C, Korf HW, Gachet C, Ikehara Y, Sévigny J, Robson SC, Zimmermann H (2006) Extracellular nucleotide signaling in adult neural stem cells: synergism with growth factor-mediated cellular proliferation. Development 133:675-684. CrossRef Medline

Nadeau S, Rivest S (2000) Role of microglial-derived tumor necrosis factor in mediating CD14 transcription and nuclear factor kappa B activity in the brain during endotoxemia. J Neurosci 20:3456-3468. Medline

Paolicelli RC, Bolasco G, Pagani F, Maggi L, Scianni M, Panzanelli P, Giustetto M, Ferreira TA, Guiducci E, Dumas L, Ragozzino D, Gross CT (2011) Synaptic pruning by microglia is necessary for normal brain development. Science 333:1456-1458. CrossRef Medline

Paxinos G, Franklin KBJ 2004 The mouse brain in stereotaxic coordinates. Amsterdam: Elsevier Academic.

Platel JC, Dave KA, Bordey A (2008) Control of neuroblast production and migration by converging GABA and glutamate signals in the postnatal forebrain. J Physiol 586:3739-3743. CrossRef Medline

Roy NS, Wang S, Jiang L, Kang J, Benraiss A, Harrison-Restelli C, Fraser RA, Couldwell WT, Kawaguchi A, Okano H, Nedergaard M, Goldman SA (2000) In vitro neurogenesis by progenitor cells isolated from the adult human hippocampus. Nat Med 6:271-277. CrossRef Medline

Schafer DP, Lehrman EK, Kautzman AG, Koyama R, Mardinly AR, Yamasaki R, Ransohoff RM, Greenberg ME, Barres BA, Stevens B (2012) Microglia sculpt postnatal neural circuits in an activity and complementdependent manner. Neuron 74:691-705. CrossRef Medline

Schafer DP, Lehrman EK, Stevens B (2013) The "quad-partite" synapse: microglia-synapse interactions in the developing and mature CNS. Glia 61:24-36. CrossRef Medline

Scheller J, Chalaris A, Schmidt-Arras D, Rose-John S (2011) The pro- and anti-inflammatory properties of the cytokine interleukin-6. Biochim Biophys Acta 1813:878-888. CrossRef Medline

Sequerra EB, Miyakoshi LM, Fróes MM, Menezes JR, Hedin-Pereira C (2010) Generation of glutamatergic neurons from postnatal and adult subventricular zone with pyramidal-like morphology. Cereb Cortex 20: 2583-2591. CrossRef Medline

Shigemoto-Mogami Y, Hoshikawa K, Goldman JE, Sekino Y, Sato K (2014) Microglia enhance neurogenesis and oligodendrogenesis in the early postnatal subventricular zone. J Neurosci 34:2231-2243. CrossRef Medline

Sierra A, Encinas JM, Deudero JJ, Chancey JH, Enikolopov G, OverstreetWadiche LS, Tsirka SE, Maletic-Savatic M (2010) Microglia shape adult hippocampal neurogenesis through apoptosis-coupled phagocytosis. Cell Stem Cell 7:483-495. CrossRef Medline

Takahashi K, Rochford CD, Neumann H (2005) Clearance of apoptotic neurons without inflammation by microglial triggering receptor expressed on myeloid cells-2. J Exp Med 201:647-657. CrossRef Medline

Takahashi K, Prinz M, Stagi M, Chechneva O, Neumann H (2007) TREM2transduced myeloid precursors mediate nervous tissue debris clearance and facilitate recovery in an animal model of multiple sclerosis. PLoS Med 4:e124. CrossRef Medline

Tang X, Falls DL, Li X, Lane T, Luskin MB (2007) Antigen-retrieval procedure for bromodeoxyuridine immunolabeling with concurrent labeling of nuclear DNA and antigens damaged by $\mathrm{HCl}$ pretreatment. J Neurosci 27:5837-5844. CrossRef Medline

Tremblay MÈ, Lowery RL, Majewska AK. (2010) Microglial interactions 
with synapses are modulated by visual experience. PLoS Biol 8:e1000527. CrossRef Medline

Tremblay MÈ, Stevens B, Sierra A, Wake H, Bessis A, Nimmerjahn A (2011) The role of microglia in the healthy brain. J Neurosci 31:16064-16069. CrossRef Medline

Ueno M, Fujita Y, Tanaka T, Nakamura Y, Kikuta J, Ishii M, Yamashita T (2013) Layer $\mathrm{V}$ cortical neurons require microglial support for survival during postnatal development. Nat Neurosci 16:543-551. CrossRef Medline

Wang S, Chandler-Militello D, Lu G, Roy NS, Zielke A, Auvergne R, Stanwood N, Geschwind D, Coppola G, Nicolis SK, Sim FJ, Goldman SA (2010) Prospective identification, isolation, and profiling of a telomerase-expressing subpopulation of human neural stem cells, using sox2 enhancer-directed fluorescence-activated cell sorting. J Neurosci 30: 14635-14648. CrossRef Medline

Wang S, Bates J, Li X, Schanz S, Chandler-Militello D, Levine C, Maherali N, Studer L, Hochedlinger K, Windrem M, Goldman SA (2013) Human
iPSC-derived oligodendrocyte progenitor cells can myelinate and rescue a mouse model of congenital hypomyelination. Cell Stem Cell 12:252-264. CrossRef Medline

Xavier AL, Lima FR, Nedergaard M, Menezes JR (2015) Ontogeny of CX3CR1-EGFP expressing cells unveil microglia as an integral component of the postnatal subventricular zone. Front Cell Neurosci 9:37. Medline

Zhao C, Teng EM, Summers RG Jr, Ming GL, Gage FH (2006) Distinct morphological stages of dentate granule neuron maturation in the adult mouse hippocampus. J Neurosci 26:3-11. CrossRef Medline

Zhao C, Deng W, Gage FH (2008) Mechanisms and functional implications of adult neurogenesis. Cell 132:645-660. CrossRef Medline

Zotova E, Holmes C, Johnston D, Neal JW, Nicoll JA, Boche D (2011) Microglial alterations in human Alzheimer's disease following Abeta42 immunization. Neuropathol Appl Neurobiol 37:513-524. CrossRef Medline 